\title{
Descentralização e good government: como aperfeiçoar o desempenho dos governos locais?
}

\section{Introdução}

O processo de descentralização avança a passos largos. O Brasil é o único país no mundo onde os municípios fazem parte da Federação e desde a Constituição de 1988, ano após ano novas responsabilidades são repassadas aos governos estaduais e municipais. Tendo iniciado pelos setores da educação e da saúde, a descentralização se expandiu para a merenda e o transporte escolar, a proteção à criança e ao adolescente, a assistência social, a vigilância sanitária, a promoção do desenvolvimento rural, a promoção do turismo, a segurança pública, o controle do trânsito, a eletrificação rural e a promoção da micro e pequena empresa. Atualmente, discute-se a municipalização do licenciamento ambiental.

Parece haver um consenso na sociedade brasileira de que a qualidade de vida do cidadão depende cada vez mais do governo local. E de que este fato é positivo. A literatura especializada ressalta as virtudes da descentralização, pois esta possibilita o aprofundamento da democracia, a maior proximidade do cidadão das instâncias decisórias, bem como a maior eficiência, eficácia e eqüidade das políticas públicas.

Todavia, uma análise mais detalhada da descentralização revela que se trata de um fenômeno bem mais complexo e, principalmente, bem mais ambíguo do que pode parecer à primeira vista. Os conflitos de interesse entre as esferas de governo, as prioridades divergentes das elites políticas locais, a aparente ampliação da corrupção e o fraco desempenho de muitos governos subnacionais em combater as maiores chagas da sociedade - a fome e a pobreza - são características do atual processo de descentralização.

Markus Brose é consultor em desenvolvimento local e metodologia participativa da Sociedade Alemã de Cooperação Técnica (GTZ) junto à

Secretaria de Planejamento do Rio Grande do Sul e mestrando em Public Policy and Management pela Universidade de Londres.

Contato: mbrose@ uol.com.br 
Assim, apesar de seus inegáveis impactos positivos, a descentralização exige uma reflexão para além da mera avaliação do desenho institucional de políticas públicas. O Governo das Mudanças no Ceará parece emblemático neste contexto. O estudo Good Government in the Tropics, uma análise de quatro programas estaduais de relativo êxito no Ceará, foi publicado em 1997 pela renomada pesquisadora Judith Tendler do Massachusetts Institute of Technology (MIT), e se tornou rapidamente um best seller internacional (Tendler, 1998). É rara a publicação norte-americana ou européia acerca de democracia, governo local e desenvolvimento sustentável que não faça referência elogiosa ao Brasil com base no referido livro (por exemplo, Hildebrand e Grindle, 1997; Turner, 1999; Abers, 2000; Véron, 2001; e Llambi e Lindemann, 2001).

Resende-Santos (2001) ressalta que a realidade e a política cearenses são mais complexas do que deixa transparecer o estudo de Tendler, e que as implicações políticas da reforma do Estado no Ceará pouco foram consideradas. Uma análise mais detalhada é apresentada por Gondim (2000), segundo a qual o Governo das Mudanças, iniciado no Ceará em 1986, efetivamente marcou o fim da República dos Coronéis que governara o Estado por 23 anos, mas criou uma nova elite — baseada no empresariado — que agora governa o Ceará ininterruptamente há 16 anos. Sobre esta nova elite, Gondim (2000: 422-424) analisa que:

"fracassou no que diz respeito à melhoria da performance do Estado por meio da valorização do servidor público (...) os resultados do modelo de desenvolvimento adotado não diferem significativamente, em termos de justiça social, dos governos neopatrimonialistas. (...) os 'governos das mudanças' perderam a oportunidade de realizar uma verdadeira reforma do Estado. (...) apesar do expressivo crescimento da economia cearense e da modernização dos métodos da gestão pública, permanece longínqua a meta de 'acabar com a miséria absoluta' no Ceará."

O debate sobre descentralização e good government na esfera subnacional demanda portanto uma qualificação das análises, um conhecimento dos detalhes e especificidades do contexto que vá além das médias estatísticas e de classificações padronizadas. A presente reflexão busca contribuir ao enriquecimento deste debate, focando no desempenho de governos locais em pequenos municípios do Rio Grande do Sul, com base em um levantamento conduzido em 15 municípios gaúchos.

Esta pesquisa procurou se pautar por quatro pesquisas anteriores de maior abrangência e envergadura. De um lado, a pesquisa pioneira realizada em 1999 pelo Instituto Brasileiro de Geografia e Estatística (IBGE), acerca da capacidade operacional das prefeituras em todo o país 
(IBGE, 2001), bem como a pesquisa nacional sobre a percepção das elites políticas das cidades de porte médio sobre democracia, realizada em 1998, sob coordenação da Universidade de São Paulo (Almeida e Carneiro, 2000) no âmbito do consórcio internacional Democracy and Local Governance (DLG, 2001). Por outro lado, duas pesquisas de âmbito regional: o estudo de Comassetto (2000), acerca da percepção de prefeitos de pequenos municípios de Santa Catarina sobre democracia e Cconselhos municipais, e o levantamento de Brose (2000), sobre práticas inovadoras de desenvolvimento local em pequenos municípios no Rio Grande do Sul.

Apesar do município atender aos requisitos mínimos exigidos em um regime democrático: voto secreto, sufrágio universal, eleições regulares, competição partidária, liberdade associativa e accountability (Lima e Cheibub, 1996), presenciamos graves desvios daquilo que deveria ser um “bom” governo local (Costa, 1997). Não nos referimos apenas à eventual corrupção, mas, principalmente, ao autoritarismo e ao alto grau de amadorismo de muitos prefeitos, concomitante com a quase auto-anulação das Câmaras Municipais. Em meados de 2001, por exemplo, a Prefeitura do município de São Lourenço do Sul obteve liminar na justiça para apreensão da edição quinzenal do jornal local que trazia reportagem sobre denúncia de improbidade administrativa feita pelo Ministério Público contra o prefeito (Zero Hora, 25 de julho de 2001). O "não roubarás" não constitui mais critério suficiente para avaliar uma gestão local, e será menos ainda no futuro.

A debilidade do governo local no pequeno município se manifesta na mais grave e visível deficiência das políticas públicas municipais: a falta de continuidade. Esta implica de sobremaneira em baixo desempenho de muitos dos governos locais de pequenos e médios municípios. Presenciamos a cada quatro anos uma política de terra arrasada, com a troca de prioridades, de instrumentos de gestão, de investimentos, inclusive quando o mesmo partido é reeleito. Parece que a cada quatro anos muitos governos locais recomeçam do zero, procurando imprimir sua própria marca ao município e buscando deliberadamente desfazer o que foi feito no governo anterior.

Neste contexto, nos movem várias indagações: Por que, apesar da existência e funcionamento de todos os mecanismos democráticos, o prefeito faz o que lhe apraz? Por que as políticas públicas municipais, em especial no interior, geralmente têm desempenho fraco? Por que não foi possível até agora obter maior continuidade nas ações locais? Procurando resposta, em suma, para a questão: Como aperfeiçoar o desempenho dos governos locais para que estes cumpram as promessas da descentralização — maior eficácia, eficiência e equiidade? 


\section{A descentralização no Brasil}

A descentralização, em sua concepção mais ampla, constitui um processo de redistribuição de poder, e assim, de direitos, recursos e responsabilidades "do governo para a sociedade civil, da União para os Estados e municípios, e do Executivo para o Legislativo e Judiciário." (Gomes e MacDowell, 2000: 8). Na descentralização administrativa, a responsabilidade pelo gasto é transferida da esfera de maior para a de menor hierarquia. $\mathrm{O}$ gasto passa a ser financiado:

a) por meio da transferência de recursos, a descentralização dependente; ou

b) mediante recursos próprios, a descentralização autônoma.

A descentralização dependente pode assumir duas formas: a descentralização dependente tutelada, que ocorre por meio de transferências negociadas e mantendo uma certa relação de dependência, ou a descentralização dependente vinculada, baseada em transferências automáticas vinculadas a critérios legalmente estabelecidos (Medici e Maciel, 1994).

A descentralização política se expressa em dois componentes principais: participação e transparência. A participação se refere primariamente à possibilidade do cidadão em escolher seus representantes e dizer a eles o que devem fazer. A transparência constitui o outro lado da moeda: a necessidade do governo local em explicar e justificar o que fez, e o que não fez (DTT, 2001).

\section{O processo histórico}

Em seu estudo sobre os resultados da descentralização na América Latina na última década, Llambi e Lindemann (2001) enfatizam que a descentralização constitui um processo histórico e não uma simples técnica administrativa de gestão pública. E por este motivo, a descentralização latino-americana apresenta resultados contraditórios, raramente alcançando os vários objetivos definidos pelos manuais de gestão pública.

As opiniões acerca da motivação para a descentralização na história brasileira são bastante diversas, e podemos identificar na literatura três linhas de argumentação:

1) uma reação à uma tradição histórica de centralismo e autoritarismo - Almeida e Carneiro (2000) e Bovo (2001) enunciam que o federalismo brasileiro tende a ser um sistema centralizado; Arretche (1996) afirma que a tendência ao centralismo foi fortalecida a partir do Governo Vargas, nos anos 30, com a centralização fiscal e a criação de burocracias federais tecnicamente preparadas e especializadas;

2) uma continuidade, pois na comparação internacional o Brasil tende a uma relativa descentralização — Souza (2001) afirma que a Federação 
brasileira é mais descentralizada, por exemplo, que a Argentina, o México

ou a França; e Fleischer (1996) argumenta que o município sempre foi a base política do país; e

3) a história brasileira é caracterizada por um processo contínuo de alternância entre centralização e descentralização — idéia defendida, por exemplo, por Souza (1998) e Aureliano (1996).

Arretche (1996) argumenta que frente ao reequilíbrio do jogo do poder brasileiro após a redemocratização e mantidas as regras atuais: presidencialismo com expressivo poder dos governadores e do Congresso, a descentralização brasileira é um processo praticamente irreversível. O que é confirmado entre outros por Farah (2001), quando a autora ressalta que a sociedade civil passou a fazer parte do policy cicle, institucionalizando-se a participação.

Mesmo com estas linhas de argumentação diferentes sobre o caráter do centralismo brasileiro, os estudos são bastante convergentes em apontar duas causas principais para a atual descentralização: a reação à ditadura militar e a crise fiscal do Estado (Affonso e Silva, 1994; Garcia, 1995).

“A motivação básica da descentralização fiscal foi de natureza eminentemente política. O processo não foi determinado por interesses precipuamente técnicos ou econômicos, não partiu de qualquer planejamento, muito menos persegue uma estratégia deliberada, com políticas bem definidas, buscando maior eficiência e eficácia nas ações governamentais. As mudanças constitucionais foram vinculadas à redemocratização do país e impostas ao governo central pelo Poder Legislativo nacional.” (Afonso, 1996: 33).

A crise do Estado desenvolvimentista e a construção de um novo pacto federativo ainda estariam em processo no âmbito da crise do federalismo (Affonso e Silva, 1994).

Segundo Arretche (1996), um ponto interessante na descentralização brasileira é que sua decisão e desenho se processa basicamente na esfera estatal. A sociedade civil dirige suas reivindicações genericamente ao poder público, e por isso se dirige em primeiro lugar à prefeitura por proximidade.

O Brasil se tornou mais federal, com o poder mais distribuído, difuso e fragmentado na esfera nacional. O Governo Federal agora precisa negociar com governos subnacionais as questões nacionais, fortalecendo a democracia. Fruto do processo de descentralização fiscal, os municípios dispõem hoje de cerca de $17 \%$ da receita fiscal disponível no país, o que equivale a 5,6\% do Produto Interno Bruto (PIB) nacional, enquanto que em 1988 eles recebiam $10,8 \%$ da receita disponível (Banco Nacional de Desenvolvimento Econômico e Social - BNDES no 28, 2001). Ao contrário da imagem negativa do Estado) que prevaleceu nas últimas duas décadas, nos anos 90, os grandes inovadores foram os governos locais, deixando de ser meros objetos do Governo Federal e se tornando sujeitos da mudança. 
Analisando os gastos sociais de 42 cidades de porte médio em São Paulo, Bovo (2001) demonstra que frente à descentralização forçada dos encargos e o aumento das demandas sociais, as decisões e iniciativas das prefeituras foram influenciadas pela redução dos gastos federais na área social. O desequilíbrio entre a oferta e a demanda fez com que na média as despesas sociais (educação, cultura, saúde, saneamento, assistência social, habitação e urbanização) no período de 1984 a 1994 passassem de $61 \%$ a $78 \%$ da receita efetiva. O autor ressalta que se entre 1984 e 1994 a receita efetiva deste grupo de municípios aumentou $\mathrm{R} \$ 930$ milhões devido à ampliação da arrecadação própria, mais de $92 \%$ do aumento da receita foi gasto na área social, sendo que o maior aumento se deu de 1984 a 1988, ou seja, ainda antes da nova Constituição. O Governo Montoro (de 1983 a 1986) teve um forte impacto na ampliação da descentralização em São Paulo (Montoro, 1990), e naquele período o déficit orçamentário deu um salto, revelando um desequilíbrio financeiro dos municípios.

\section{Argumentos acerca \\ da descentralização}

Os diversos estudos consultados para o presente trabalho são unanimamente favoráveis à descentralização, ressaltando as suas várias vantagens, mas apontando alguns riscos conforme está sistematizado no Quadro 1. A pesquisa de Almeida e Carneiro (2000) demonstra que as elites políticas locais, à semelhança das elites federais, são hoje em dia ainda mais favoráveis à descentralização do que eram há 20 anos.

\section{Quadro 1: Quadro de forças da descentralização no Brasil}

\begin{tabular}{|c|c|}
\hline Democratização do país & $\begin{array}{l}\text { Descentralização desorganizada } \\
\text { gerando incertezas }\end{array}$ \\
\hline Participação popular & Falta de controle social \\
\hline Controle sobre os governantes & $\begin{array}{l}\text { Reação das elites locais e novas } \\
\text { formas de cooptação }\end{array}$ \\
\hline $\begin{array}{r}\text { + Eficiência e eficácia das } \\
\text { políticas públicas }\end{array}$ & Descontinuidade nas políticas públicas - \\
\hline Desenvolvimento sustentável & Incompetência dos Conselhos municipais \\
\hline Criação de novos espaços públicos & $\begin{array}{l}\text { Repasse de responsabilidade e não } \\
\text { de know how }\end{array}$ \\
\hline Formação de novas lideranças & $\begin{array}{l}\text { Recursos não são transferidos no } \\
\text { montante exigido }\end{array}$ \\
\hline Riscos da descentralização são menores & Setorialização das políticas \\
\hline Regulação da economia & Menor eficácia do Estado \\
\hline
\end{tabular}


As diferenças entre os autores consultados estão mais na avaliação

que fazem dos resultados — ou da falta deles — da descentralização, e qual aspecto enfatizam em seus estudos. Llambi e Lindemann (2001), bem como DLG (2001), enfatizam a importância da descentralização para a estabilidade política, e portanto para o desenvolvimento. Figueiredo (1997: 8) destaca a importância para o controle social:

"Governadores e presidente da República são inacessíveis aos cidadãos comuns. Do ponto de vista prático, não são muito diferentes do artista da televisão. Já o prefeito não. Ele é cobrado diariamente pelos munícipios, os vereadores transmitem os problemas, muitas vezes a própria casa do prefeito fica cercada de gente. Nesse contexto, ou o prefeito faz ou fica com a fama de incompetente, já que a população está longe de saber exatamente qual a esfera de governo faz o quê."

\section{Limitantes no atual processo de descentralização}

Com poucas exceções, a maioria dos setores sociais do Estado foi descentralizada, mas cada setor de uma forma diferente, não existindo um padrão único. Em um ponto, a literatura consultada é bastante convergente: a atual descentralização está se dando de forma aleatória, desorganizada, sem planejamento ou articulação entre as três esferas de governo, deste modo, prejudicando a capacidade operacional dos governos locais. Resende (2000), por exemplo, apresenta um estudo de caso acerca das limitações da descentralização de programas de combate à fome.

"Muitos estudos têm mostrado que a descentralização foi adotada sem uma compreensão mais profunda das questões envolvidas. A descentralização da educação e da saúde, por exemplo, foi feita sem se avaliar a capacidade administrativa e financeira dos municípios, que varia enormemente. A descentralização não ocorre em um vazio, mas, ao contrário, requer uma complexa engenharia político-institucional. Em muitos municípios, essas políticas apresentam resultados desanimadores." (Souza, 2001: 19).

Neste contexto, destoa a análise do BNDES de que "contrastados indicadores físicos e financeiros da rede municipal, verifica-se que a taxa de expansão dos serviços prestados supera a do gasto estimado, o que (...) sugere que a municipalização do ensino e da saúde provocou melhoria da racionalização e eficiência do gasto público.” (BNDES, nํㅡㄹ 23, 2001).

Já Aureliano (1996) afirma que o único setor com descentralização planejada é a saúde, sendo a descentralização no restante mero processo 
reativo. Segundo a autora, não houve qualquer resultado palpável em termos de eqüidade, eficiência, participação e controle social na descentralização. Para Jacobi (2000: 52), as limitações são tantas que: “A descentralização não tem produzido uma mudança substancial no modelo vigente, tendo-se restringido mais a um processo administrativo sem real transferência de poder". O que estaria ocorrendo é uma municipalização tutelada, em que o município é igualado à prefeitura. Gomes e MacDowell (2000) enfatizam o impacto negativo da descentralização fiscal por meio da criação de excessivo número de pequenos municípios, e a crescente transferência de impostos dos Estados e da União aos mesmos.

De acordo com a análise de Afonso (1996: 32):

"No Brasil desenvolve-se um dos processos de descentralização fiscal mais peculiares do mundo. (...) O país apresenta disparidades tão acentuadas como as da Índia; incorre em custos financeiros para manter a unidade nacional tão elevados como os do Canadá; suas relações intergovernamentais são tão complexas, desorganizadas e desarticuladas como as da Rússia - sem contar que as unidades federais 'guerreiam' entre si (através de incentivos fiscais) como as da antiga Iugoslávia."

As políticas setoriais de habitação e saneamento são um exemplo de descentralização por default, em que os municípios vêm assumindo novas responsabilidades na medida em que o Governo Federal se recusa a atuar nestes setores. Por outro lado, constata-se uma intensificação de práticas clientelistas nos municípios. O desequilíbrio regional, que a Constituição de 1988 queria minimizar, aumentou nos anos 90 com o avanço da industrialização na região Sudeste. A Constituição de 1988 ampliou o papel do Estado na redução dos desequilíbrios internos, mas assim que começou a vigorar teve início a política do Governo Federal de diminuição do papel do Estado. Além disso, a estabilização da moeda em 1994 restaurou a tradição brasileira de presidentes fortes (Souza, 2001).

A descentralização avança com rapidez, talvez com uma rapidez excessiva, fortalecendo a democracia. Mas, por enquanto, as decisões ainda estão - paradoxalmente - centradas nas capitais. Mesmo que o processo de descentralização tenha se iniciado efetivamente antes da sua formalização em 1988, ele ainda se caracteriza por uma alto grau de incerteza, dada a ausência de um marco referencial geral, de um planejamento mais detalhado ou mesmo de um acordo entre as esferas de governo quanto à sua extensão. Se faz necessário tornar a descentralização mais pausada, mais previsível, com clara atribuição de funções e de fontes de financiamento a cada esfera de governo. $\mathrm{O}$ aumento das responsabilidades aos governos locais deve ser concomitante à expansão 
do repasse de recursos e de know how, estabelecendo-se claros padrões de qualidade para os serviços públicos. No momento, esta demanda ainda se encontra na contramão da tendência de recentralização pelo Governo Federal no âmbito dos ajustes macroeconômicos, e na drenagem fiscal em que estes implicam.

\section{Origem e evolução do município brasileiro}

O município, como unidade político-administrativa, surgiu na Penísula Ibérica com a criação em 206 a.C. da primeira colônia romana naquela região (Curchin, 1990). Anteriormente, existia uma grande diversidade de formas locais de governo na Penísula Ibérica: tribos celtas; pequenos principados, cidade e colônias gregas e cartaginesas. A República romana concedia às cidades conquistadas, ou às novas colônias, o privilégio de escolher seu próprio governo desde que reconhecessem a soberania do Senado romano. A autonomia municipal foi uma das principais características do Estado romano, pois a administração local autônoma, com eleições anuais regulares das lideranças políticas, foi o modelo encontrado por Roma para evitar o retorno da monarquia (Mackie, 1983).

O modelo seguido nas cidades das províncias, incluindo portanto a Lusitânia, era o da estrutura administrativa de Roma: um conselho gestor e um corpo de juízes (Galsterer, 1971). Inicialmente, a autonomia esteve restrita à cidades italianas, mas em 90 a.C. com a Julia Lex de Civitate este privilégio foi estendido às cidades das províncias, aprofundado pela concessão da cidadania romana em 45 a.C. por Júlio César que pretendia modernizar e uniformizar os governos locais (Smith, 1875).

A tradição de autogoverno local se manteve ao longo do tempo durante o reino dos Visigodos, iniciado no ano de 416, sofrendo algumas adaptações a partir das tradições árabes durante o Califado de Córdoba, iniciado no ano de 711. Com o estabelecimento do reino português, a partir de 1179, o direito das cidades em editarem suas próprias leis foi reconhecido pelo rei, que concedia cartas forais às Câmaras Municipais. Em 1446, a publicação das Ordenações Alfonsinas criou, entre outras medidas modernizadoras, uma legislação única para as Câmaras (Ferreia, 1980).

A estrutura administrativa portuguesa dos municípios se consolidou com o tempo e foi transferida ao Brasil com o início da colonização. O primeiro município brasileiro foi São Vicente, fundado em 1532, criando um dos primeiros governos locais autônomos da colonização das Américas. Apenas em 1537, seguiu-se a fundação de Olinda e em 1545, a cidade de Santos (Castro, 1999). 
O município tinha caráter estritamente urbano e feições jurídicas republicanas. Os homens de bem da cidade escolhiam o Conselho Municipal composto por nove vereadores, um secretário e um procurador para os assuntos administrativos, sendo que as Câmaras Municipais no Brasil dispunham de maior autonomia que as Câmaras Municipais portuguesas. "O rei encarnava uma rede de poderes militares, políticos e administrativos, disseminados por todo o Império. O poder local funcionava então como um contraponto da centralização monárquica, gozando de relativa autonomia." (Souza, 1999: 144). Existia uma relação direta entre as Câmaras e o rei de Portugal, e as Câmaras das cidades mais ricas mantinham representantes diplomáticos na corte que solicitavam para as Câmaras brasileiras os mesmos privilégios da cidade do Porto, que gozava de maior autonomia que Lisboa.

Ferreira (1980) enfatiza que as Câmaras eram constituídas dos três poderes: Executivo, Legislativo e Judiciário, e por isso eram conhecidas como Repúblicas. Segundo o autor, o termo correto seria Repúblicas municipais da monarquia portuguesa no Brasil.

A importância e o papel relevante das Câmaras de Salvador, Belém, São Luís do Maranhão, do Rio e de Vila Rica, na consolidação do reconhecimento de D. Pedro I e da independência de Portugal, são destacados por Souza (1999). Para D. Pedro I tornar-se Imperador, foi necessário estabelecer um novo contrato social entre si e as Câmaras Municipais, substituindo o contrato social anterior existente com o rei de Portugal. As Câmaras brasileiras consentiram ser regidas por um novo soberano, enfatizando em suas correspondências que a origem do poder residia no povo, e que este — por intermédio das Câmaras - o depositava em D. Pedro I. A nova Constituição do Império do Brasil, outorgada por D. Pedro I em 1823, teve que ser ratificada pelas Câmaras para entrar em vigor.

A nova modernização do governo local ocorreu quando o cargo de prefeito foi instituído pela primeira vez na província de São Paulo pela lei no 18 de 11 de abril de 1835 (Meirelles, 1977). O prefeito era nomeado pelo presidente da província e a iniciativa obteve tanto sucesso na administração local que o Governo Imperial no Rio de Janeiro editou um decreto recomendando a inovação às demais províncias no mesmo ano.

No final do século XIX, entre outros por motivo do entusiasmo gerado com a divulgação da obra de Tocqueville, nasce a bandeira municipalista no Brasil (Melo, 1993). A questão da maior autonomia municipal e provincial era parte fundamental da crítica política dos liberais ao Imperador. Os municipalistas defendiam o local self-government por meio da descentralização administrativa e a ampliação da participação política pela 
generalização das eleições, seguindo o modelo dos EUA, deste modo se contrapondo ao modelo monárquico, unitarista e centralizador de inspiração francesa adotado no Império brasileiro.

\section{O município na República}

Como muitas outras, a primeira Constituição Federal brasileira de 1891 foi baseada na Constituição dos EUA, datada de 1787, que não trata dos municípios (Jordan, 2001; Elliot e Ali, 1995), acabando por limitar o raio de ação do governo local na República.

Frente ao processo de urbanização e industrialização do país, acelerado pela decretação da República e a recém-criada Federação, houve uma fusão entre a idéia do municipalismo e o ruralismo. Cria-se em certa parcela da elite política nacional a noção ideológica de que o Brasil seria uma nação de vocação eminentemente agrária. E de que havia uma disjunção entre o país real, estruturado por clãs locais dispersos nos municípios de um imenso território, o mundo rural, e o país legal, idealizado, federalizado e governado a partir do Rio de Janeiro, o país urbano. Segundo esta visão, para governar o país era necessário um Estado forte e centralizado, desta forma fornecendo as bases ideológicas para a ditadura de Vargas nos anos 30. Vargas era um militar oriundo de uma tradição autoritária, mas ao mesmo tempo municipalista, no Rio Grande do Sul.

A criação de novos órgãos pelo Governo Vargas, essenciais à estratégia de modernização do país, foi fortemente influenciada pelo ideário municipalista. "Após a Revolução de 30 e particularmente durante o Estado Novo, o municipalismo foi elevado à condição de princípio programático das elites e de peça importante da estratégia de nation-building perseguida." (Melo, 1993: 88). Em uma atitude paradoxal, intelectuais do regime propunham a reorganização do país em uma Federação de municípios, enquanto a Constituição de 1937 era profundamente centralizadora.

Durante a redemocratização de 1945, o municipalismo ressurge com força, vindo a ter forte espaço na discussão da Constituição de 1946, que amplia a ação do governo local, mas acaba consolidando a subordinação política do município aos governos estaduais. A este respeito comenta Silva (1952: 50) a lei mineira de organização municipal: "Com fundamento nestes dados, a conclusão só pode ser no sentido de que cabe aos Estados prover à organização de seus próprios municípios. E esta é a solução justa, porque, se aos Estados-membros compete criar os municípios, é de argumentar-se que o poder de criação implica necessariamente no de organização".

Durante a campanha presidencial, o tema recebeu amplo destaque, sendo criada nesta época a Associação Brasileira de Municípios (ABM). Porém, o conceito de município era vago e ambíguo, permitindo incorporar 
a um só tempo a ideologia rural da ditadura do Estado Novo e a crítica ao centralismo ocorrida no período. O problema do município era visto inclusive como um "problema tipicamente agrário" por alguns pensadores, e não como uma questão de autonomia política.

Nos anos 50, ocorre um intenso debate público e uma produção intelectual sobre o papel do município no país, em especial a partir da realização dos primeiros congressos nacionais dos municípios e a criação do Instituto Brasileiro de Administração Municipal (IBAM) em 1952. No final deste período, o programa de cooperação técnica em administração pública, firmado com a USAID, dá origem, entre outras ações, à Escola Brasileira de Administração Pública (EBAP) no Rio de Janeiro, envolvendo o treinamento de 646 técnicos brasileiros em administração pública dos quais 60 em administração municipal.

Segundo Melo (1993: 94), “o centralismo burocrático era atacado sobretudo por esvaziar áreas rurais. Nessa perspectiva, o conteúdo substantivo do municipalismo era a reversão do abandono das populações rurais. Tal abandono resultava da expansão desigual — porque restrita aos núcleos urbanos de maior porte - da esfera pública sobre o território". Para os congressistas paulistas, contrários à realização de convênios e repasse de recursos entre o Governo Federal e os municípios, o municipalismo deveria ser equivalente à autonomia política e financeira, incluindo portanto arrecadação própria.

Ao longo das décadas de 50 e 60, foram sendo ampliados os serviços de organização e modernização das prefeituras, inclusive com a criação de um concurso anual dos cinco municípios de "maior progresso" no país. Com o decreto no 59.917, de 30 de dezembro de 1956, foi regulamentado pela União o Serviço Federal de Habitação e Urbanismo (SERFHAU), estabelecendo também o Fundo de Financiamento de Planos de Desenvolvimento Local Integrado (FIPLAN). Foi inaugurada assim a cultura da eficiência em esfera municipal no país. A modernização da gestão pública com caráter urbano constituiu uma dimensão central da expansão da esfera pública e, portanto, da construção do moderno Estado brasileiro. Conforme ressalta Melo (1993: 96):

“o projeto de modernização da gestão municipal tinha como paradigma histórico a reforma municipal norte-americana da Progressive Era (1900-1914). O projeto de reforma de gestão nos EUA buscava isolar a burocracia dos governos locais da influência das political machines. Entre suas principais inovações estava a criação de um Executivo municipal técnico, o city manager — em lugar de um comitê de veradores. (...) buscando revolucionar a cultura política norte-americana do século XIX, dominada, como a brasileira, por forte clientelismo e patronagem." 
Essa influência, no entanto, ficou restrita nos EUA aos grandes centros urbanos. Carneiro (1931) cita o Relatório da National Municipal League dos EUA, datado de 1917: “O governo do município é a mais atrasada de todas as nossas unidades políticas, a mais negligenciada pelo público, a mais autoritária, a menos eficientemente organizada, a mais corrupta e incompetente, e, por motivos de complicações constitucionais, a mais difícil de reforma."

As mudanças nos EUA começaram de forma localizada, mas se expandiram com o tempo, criando um novo paradigma na gestão local. A função do city manager contratado, e não eleito, para gerir o município foi criada em 1908 com o objetivo de combater a corrupção e a falta de preparo técnico das lideranças políticas. Os requisitos mínimos para a profissão de city manager passaram a ser um curso aprofundado de gestão pública e experiência prática mínima de três anos. A Câmara mantém o controle, mas o Executivo não-eleito é que dirige as ações do município. A eleição deixou de ser critério para escolha do prefeito (Jameson, 1965).

Enquanto a reforma nos EUA possibilitou a construção da capacidade do Estado prioritariamente nos níveis municipal e estadual, a reforma brasileira dos anos 50/60 se restringiu em larga escala ao nível federal. Uma pesquisa nacional realizada em 1965 pelo convênio Fundação Getúlio Vargas (FGV)/Fundação Ford sobre administração pública no Brasil não detectou nenhuma instância de formação para governos locais no país, somente cursos para gestores públicos das esferas federal e estadual (Machado, 1966). A principal diferença entre os dois casos está no contexto social. Enquanto nos EUA se tratava de construir uma burocracia profissionalizada com um sistema partidário e de democracia de massas já consolidados, no Brasil, assim como foi na Alemanha e na França, a emergência de uma burocracia profissionalizada precedera a emergência dos partidos. Porém, no caso brasileiro, a burocracia que se consolidou durante o Império, na segunda metade do século XIX, restringia-se ao poder central e foi largamente desarticulada com a criação da Federação.

\section{O município na ditadura}

Inicialmente, a descentralização fazia parte do programa dos militares no golpe de 1964 para possibilitar maior eficiência do setor público e combater a corrupção (Brasil, 1969; Sato, 1993). Pós-64 houve inclusive um aumento da transferência de recursos do Governo Federal para os municípios (Arretche, 1996) e o decreto-lei no 200, de 25 de fevereiro de 1967, deu forma à descentralização do Estado. A Emenda no 1 à Constituição, feita em 1969, objetivava deixar os pleitos municipais menos federalizados (Fleischer, 1996). Segundo relato de 1969: 
"As causas mais importantes do entravamento do serviço público são: centralização interna no Governo Federal; execução direta pelo Governo Federal; centralização dos poderes na União em detrimento dos governos locais; leis minuciosas; falta de continuidade administrativa; falta de bons governos. Bom governo, de formação democrática, capaz, honesto, eis a grande solução.” (Brasil, 1969).

Porém, a partir do golpe em 1968, a centralização do país alcança nos anos 70 um patamar sem precedentes. A formidável concentração de recursos fiscais em Brasília facilita uma sequiência de grandes escândalos de corrupção envolvendo valores cada vez maiores (Assis, 1984).

Mesmo durante a ditadura, não houve interrupção das eleições municipais e certos programas sociais eram descentralizados, possibilitando a continuidade no processo de formação de lideranças políticas: "a forma de expansão do Estado realizada durante o regime militar implicaria a criação de capacidades institucionais e administrativas nos estados e municípios, capacidades estas que explicam em parte a natureza do processo de descentralização" (Arretche, 1996: 52). A institucionalização do planejamento se disseminou nas administrações locais por meio das Leis Orgânicas dos municípios, que eram elaboradas pelos respectivos governos estaduais. "O Plano Diretor de Desenvolvimento Integrado foi uma exigência imposta pelos Governos Estaduais aos Municípios para a obtenção de auxílio financeiro e transferência de recursos." (Saule Jr., 1997: 35).

\section{O município na redemocratização}

A longa transição para a democracia, iniciada no final dos anos 70, reverte a tendência e, na Assembléia Constituinte de 1986/87, a reação à ditadura e o desejo de maior controle sobre os governantes se faz sentir em toda sua força, criando o federalismo municipal (Gomes e MacDowell, 2000). A Constituição de 1988 é essencialmente descentralizadora, criando um federalismo cooperativo (Almeida e Carneiro, 2000), com ênfase não nos governos estaduais, mas nos governos locais. Caso único nos sistemas federais contemporâneos, o município foi transformado em ente federativo. Sua criação depende da vontade da população local e não mais de leis estaduais ou federais. O município ganhou autonomia política, administrativa, legislativa e financeira. A legislação criada nos anos 90, regulamentando a Constituição, consolidou a descentralização em praticamente todas as áreas, em especial, nas políticas sociais, com exceção da previdência.

A consolidação da descentralização é ressaltada por Figueiredo (1997): em 1984 os candidatos a prefeito nas capitais discutiram a Nova 
República, em 1988 a Assembléia Constituinte dominou as eleições, em

1992 a campanha eleitoral foi marcada pela desilusão do eleitor com os políticos e o impeachment de Collor. Em 1996, ocorreu a primeira eleição para prefeitos, na qual os temas municipais prevaleceram e não foi possível federalizar a campanha. E, desde então, o tema central das campanhas vem sendo basicamente a eficiência da administração anterior.

Apesar de uma longa tradição e riqueza de experiências organizacionais, boa parcela da tradição histórica do autogoverno local é desconhecida no Brasil. Os estudos municipais são uma disciplina incipiente, desta forma limitando o aprendizado organizacional e a gestão de conhecimento por parte dos atores atualmente responsáveis pela condução dos governos locais. Ainda é frágil a consciência acerca do elevado grau de autonomia concedido às prefeituras, e mais ainda às Câmaras, a partir de 1988. Para maior aproveitamento do potencial de autonomia existente na legislação, as prefeituras, por meio das associações de prefeitos, as Câmaras, por meio da união de vereadores, e a sociedade civil organizada deverão ampliar suas ações de influência e controle nas esferas estadual e nacional na defesa de seus interesses.

\section{Os municípios gaúchos}

Com 10,2 milhões de habitantes, o Rio Grande do Sul compreende $6 \%$ da população brasileira, detendo $8 \%$ do PIB nacional. Muitos indicadores sociais do Rio Grande do Sul são superiores à média nacional. Enquanto em 1999 o PIB per capita nacional era de U\$ 3.320/ano, no Rio Grande do Sul era de U\$ 4.450/ano. No Rio Grande do Sul, a população tem em média nove anos de estudo e 71,8 anos de expectativa de vida. Nas áreas urbanas, $98 \%$ da população tem luz, $81 \%$ tem água tratada e $83 \%$ é atendida pela coleta de lixo (FEE, 1999).

Porém, como em nível nacional, também no Rio Grande do Sul as médias estatísticas mascaram as desigualdades sociais e graves desequilíbrios microregionais. No Rio Grande do Sul, os $20 \%$ mais pobres detêm apenas $2,7 \%$ da riqueza. E a tendência é de concentração, pois enquanto que em 1990 os $10 \%$ mais ricos detinham 15,3\% da riqueza, em 2000 já eram 19,4\%. Em 1999, um total de 1,1 milhão (11\% do total) de gaúchos vivia em situação de miséria (<1 salário mínimo/mês) e um total de cerca de $30 \%$ das famílias vivia abaixo da linha de pobreza (Zero Hora, 30 de agosto de 2001).

No que concerne aos governos locais, a tendência histórica sintetizada na Tabela 1 tem sido a continuada emancipação e a criação de municípios cada vez menores, em especial após 1985. Não são poucos os entusiastas deste processo de fragmentação: atualmente estão protocolados 
na Assembléia Legislativa do Rio Grande do Sul um total de 109 pedidos de realização de plebiscito para criação de novos municípios (Correio do Povo, 16 de julho de 2001; veja também Klering, 1998).

Tabela 1: Quadro resumo da criação de municípios no Rio Grande do Sul

\begin{tabular}{l|c|c|c}
\hline Ano & Total / municípios & Ano & Total / municípios \\
\hline 1810 & 4 & 1930 & 80 \\
\hline 1830 & 7 & 1950 & 92 \\
\hline 1850 & 21 & 1970 & 152 \\
\hline 1870 & 30 & 1980 & 232 \\
\hline 1900 & 66 & 1990 & 333 \\
\hline 1910 & 67 & 1995 & 467 \\
\hline 1920 & 72 & 2000 & 497 \\
\hline
\end{tabular}

Fonte: adaptado de FEE (1999).

A primeira Constituição gaúcha foi redigida no final de 1842 e aprovada em Alegrete em fevereiro de 1843 em plena Guerra dos Farrapos, caracterizando o Rio Grande do Sul como República independente (Flores, 1985). O capítulo VII, referente ao governo local, copiava a redação da lei de $1^{\circ}$ de outubro de 1828 de D. Pedro I, que regulamentava a Constituição do Império de 1823, prevendo que as Câmaras seriam "corporações meramente administrativas" com eleição direta e quatro sessões ao ano. Cada cidade ou vila seria administrada por um diretor nomeado pelo governo de Porto Alegre.

A modernização veio com a primeira Constituição como Estado membro da Federação. Aprovada em julho de 1891, o texto foi inspirado pelos ideais do positivismo e previa o autogoverno nos municípios. O presidente da província e principal redator desta Constituição, tendo lido estudos sobre os municípios norte-americanos — em muitos casos meros apêndices dos governos estaduais - pretendia que os municípios gaúchos tivessem maior autonomia. $\mathrm{O}$ conselho e o intendente municipal seriam eleitos diretamente para mandatos de quatro anos, e o artigo 64 previa: "Na sua primeira sessão, o conselho elaborará a lei orgânica municipal, que promulgada pelo intendente regerá o município. Nessa lei será (...) prescrito tudo o que for da competência do município". (Estado do Rio Grande do Sul, 1963). A Constituição gaúcha de 1935 previa a criação de um órgão de assistência técnica às administrações municipais.

Enquanto os municípios brasileiros tiveram a obrigatoriedade - e o direito — de redação de uma Lei Orgânica própria definida, apenas na 
Constituição de 1988, os municípios gaúchos dispunham desta possibilidade

já desde 1891. O que causou acalorados debates entre municipalistas nos anos 50, motivando inclusive a defesa de uma "República Municipalista" (Oliveira, 1958). A Constituição brasileira dos militares em 1967 previa a competência dos governos estaduais para elaborar a Lei Orgânica dos Municípios, abrindo a exceção para o Rio Grande do Sul (Saule Jr., 1997). E nos anos 70, os governos estaduais atualizaram as leis de regulamentação dos municípios, exceto no Rio Grande do Sul (Brasil, 1976).

Além da tradição de autonomia municipal, uma das principais características do Rio Grande do Sul é que a grande maioria dos seus municípios tem caráter rural. Em sua reflexão sobre o meio rural, Abramovay (2000: 2) ressalta que "há um vício de raciocínio na maneira de se definir as áreas rurais no Brasil". O rural é definido pelos órgãos públicos em grande parte como "resíduo": as áreas rurais são aquelas fora dos limites da cidade no município. Desde que haja extensão de serviços públicos a um determinado aglomerado populacional, ele tende a ser classificado como urbano, e o rural tenderá a ser classificado pela carência.

No Rio Grande do Sul, o órgão encarregado da assistência aos municípios, extinto em 1995, tinha a denominação de Superintendência do Desenvolvimento Urbano e Administração Municipal (SURBAM), denotando já em seu nome as suas prioridades. Em seu manual Administrando o Município, datado de 1988, a SURBAM detalha as quatro responsabilidades da administração municipal:

1) ordenamento territorial (perímetro urbano);

2) serviços públicos (limpeza urbana, pavimentação, conservação de praças, cemitérios, iluminação de vias urbanas etc.);

3) preservação do Patrimônio Natural e Cultural (prédios, matas, festas, tradições etc.); e

4) higiene, segurança e ordem pública.

Um enfoque que iguala municipal ao urbano, e à cidade. Porém, "ruralidade é um conceito de natureza territorial, e não setorial. As cidades não são definidas pelas indústrias, nem o campo pela agricultura." (Abramovay, 2000: 6; veja também Veiga, 2000).

O espaço rural, se entendido como áreas não-densamente povoadas, inclui o conceito de cidades rurais que caracteriza a grande maioria dos municípios gaúchos. Sendo severo na classificação, pode-se caracterizar como municípios rurais aqueles com 1.000 a 20.000 habitantes. Adotando uma classificação mais detalhada, é possível incluir os municípios com 20.000 a 50.000 habitantes e mesmo alguns até 100.000 habitantes.

Dos 5.559 municípios brasileiros, 4.119 têm menos de 20.000 habitantes e 908 têm de 20.000 a 50.000 habitantes (IBGE, 2001), o que equivale a dizer que cerca de $90 \%$ dos municípios brasileiros — abrangendo cerca de 60 milhões de pessoas — têm caráter rural. Nestes municípios, 
vivem 55\% dos mais pobres (Garcia, 1995). Dos 467 municípios gaúchos, cerca de 400 podem ser considerados municípios rurais. Como $25 \%$ da população do Rio Grande do Sul vive em municípios com até 20.000 habitantes e $14 \%$ vive em municípios de 20.000 a 50.000 habitantes, pode-se estimar que cerca de um terço da população do Estado vive em municípios de caráter rural.

Nos debates e definições de políticas públicas, muitas vezes não são reconhecidas as especificidades, as limitações e os potenciais deste grande conjunto de municípios. Por exemplo, quanto ao fato de vários municípios no topo do ranking nacional de qualidade de vida serem municípios rurais (PNUD, 1998), implicando em que grande parte das políticas públicas voltadas aos municípios tenham caráter essencialmente "urbano". Na bibliografia consultada, apenas Garcia (1995), Mendonza e Lira (1998) e Llambi e Lindemann (2001) ressaltam as características específicas de municípios de caráter rural.

"Municípios, de modo geral, têm sido pensados de forma unilateral por técnicos de visão essencialmente urbanística, sem vínculos, nem formação para articular o rural e a natureza ao processo de desenvolvimento. O resultado, quase que invariavelmente, é a subordinação absoluta do território à lógica predatória dos mercados. 'Foi um erro grosseiro do urbanismo. Considerar o asfalto, o concreto e a indústria sinônimos do progresso e de redenção para o 'atraso rural' (...) Na verdade, a expressão planejamento urbano é imprópria. O correto é planejar o ambiente do homem como um todo'." (Cerri, 2001).

Llambi e Lindemann (2001) enfatizam que de um modo geral os governos de pequenos municípios na América Latina enfrentam sérias limitações. As prefeituras dispõem de um reduzido quadro técnico, desconhecem grande parte dos procedimentos do Governo Federal, têm acesso restrito a recursos financeiros e possuem limitada capacidade para elaboração de projetos próprios. Os autores recomendam que o fortalecimento institucional do governo local deve ter prioridade nos processos de descentralização, contradizendo a prática brasileira em que as políticas do Governo Federal e dos governos estaduais se caracterizam pelo alto grau de desconfiança em relação aos governos locais. A tentativa de exercer um controle cada vez mais rigoroso sobre o município chega em certas políticas públicas brasileiras ao limite da inconstitucionalidade: "O nosso federalismo se encontra fortemente comprometido, assim como nossa democracia, por um governo federal altamente centralizador e autoritário, portanto, inconstitucional.” (Magalhães, 2000: 15).

Não basta esperar que os municípios de caráter rural, de modo simplista classificados como "regiões economicamente atrasadas" (Lagemann e 
Bordin, 1993), algum dia comecem a experimentar um forte crescimento econômico e passem então a ser classificados como "urbanos", se tornando então mais confiáveis e "modernos". As políticas públicas voltadas para estes municípios precisam ser adequadas às suas especificidades. Adescentralização é essencialmente a redistribuição de poder, e a bibliografia sobre descentralização aqui consultada tende a tratar os governos subnacionais de modo uniforme, resistindo a aceitar o fato de que as políticas descentralizadoras podem produzir resultados diferenciados entre os poucos e extensos núcleos urbanos das metrópoles e a grande maioria dos pequenos municípios de caráter rural.

Tendo em vista o seu contexto específico, no Rio Grande do Sul, torna-se urgente estancar o desmembramento de novos municípios e estimular a formação de consórcios intermunicipais para conferir viabilidade técnica e financeira ao grande número de políticas públicas que foram descentralizadas. Diante de uma rica história e tradição de autogoverno local, deve ser factível passar de uma cultura do "planejamento urbano" para uma cultura do "desenvolvimento municipal" no Estado, dissociando tanto o conceito de "município" do conceito de "prefeitura", como dissociando a idéia de "município" da idéia de "cidade". É necessário fortalecer a capacidade operacional dos governos locais, em especial na maioria dos municípios que são de caráter rural, por meio de ações de capacitação, formação e modernização da gestão. Este esforço deve ser acompanhado de inovações na ampliação de linhas de financiamento e tecnologias financeiras para investimentos públicos no município, extrapolando a fragmentação existente entre ministérios/ secretarias estaduais da agricultura, e os ministérios/secretarias estaduais de políticas "urbanas".

\section{Resultados do levantamento}

Entre junho e agosto de 2001, foram realizadas entrevistas com 26 pessoas, integrantes das elites locais, em 15 municípios do Rio Grande do Sul, além de duas entrevistas feitas em Porto Alegre, totalizando 28 entrevistas. Foram visitados municípios de caráter rural — no sentido lato - a maioria tendo sido escolhida ao acaso no entorno das universidades que, por meio de seus programas de extensão, apoiaram este levantamento: Universidade de Santa Cruz do Sul (UNISC), Universidade Regional Integrada (URI/Santiago) e Universidade de Ijuí (UNIJUI/Santa Rosa). Uma exceção foi feita no caso de Pelotas, município com cidade de porte médio mas que se caracteriza por dispor de uma área rural com mais de 20.000 habitantes. A Tabela 2 apresenta uma caracterização destes municípios. 
Tabela 2: Municípios visitados

para a realização de entrevistas

\begin{tabular}{r|l|r|r|r|r|l}
\hline & Município & $\begin{array}{r}\text { Área } \\
\mathrm{Km}^{2}\end{array}$ & $\begin{array}{c}\text { Hab. } \\
\text { urbano }\end{array}$ & $\begin{array}{r}\text { Hab. } \\
\text { rural }\end{array}$ & $\begin{array}{c}\text { Hab. } \\
\text { total }\end{array}$ & Classificação* \\
\hline 01 & Harmonia & 48 & 1.781 & 1.878 & 3.659 & Micromunicípio \\
\hline 02 & Barão & 109 & 2.290 & 3.106 & 5.396 & Município muito pequeno \\
\hline 03 & Tucunduva & 188 & 3.847 & 2.456 & 6.303 & Município muito pequeno \\
\hline 04 & Campina das Missões & 218 & 2.274 & 4.736 & 7.010 & Município muito pequeno \\
\hline 05 & Tuparendi & 303 & 5.110 & 4.433 & 9.543 & Município muito pequeno \\
\hline 06 & Vale do Sol & 327 & 720 & 9.837 & 10.557 & Município muito pequeno \\
\hline 07 & Jaguari & 694 & 6.624 & 5.865 & 12.489 & Município muito pequeno \\
\hline 08 & Vera Cruz & 311 & 9.901 & 11.402 & 21.303 & Município médio \\
\hline 09 & Três Passos & 272 & 18.142 & 6.512 & 24.654 & Município médio \\
\hline 10 & Rio Pardo & 2.134 & 26.036 & 11.742 & 37.778 & Município médio \\
\hline 11 & Canguçu & 3.841 & 17.685 & 33.742 & 51.427 & Município médio \\
\hline 12 & Santiago & 3.255 & 45.043 & 7.051 & 52.094 & Município médio \\
\hline 13 & Santa Rosa & 488 & 55.968 & 9.066 & 65.034 & Município médio \\
\hline 14 & Santa Cruz do Sul & 799 & 93.650 & 13.851 & 107.501 & Município grande \\
\hline 15 & Pelotas & 1.678 & 300.952 & 22.082 & 323.034 & Município grande \\
\hline
\end{tabular}

Fonte: dados extraídos do Censo 2000 (IBGE)

(*) Segundo Gomes e MacDowell (2000)

Na maioria dos casos, as pessoas entrevistadas foram selecionadas a partir de sugestões de contatos nas universidades. A Tabela 3 resume as principais características das quatro mulheres e 24 homens entrevistados quanto ao grau de instrução e posição política.

Tabela 3: Caracterização dos entrevistados

\begin{tabular}{l|r|r|l|c|c}
\hline Grau de escolaridade & & & Posição política declarada & & \\
\hline Primeiro grau incompleto & 2 & $7,1 \%$ & & & \\
\hline Segundo grau incompleto & 1 & $3,5 \%$ & Direita & 0 & - \\
\hline Segundo grau completo & 6 & $21,4 \%$ & Centro & 13 & $46,4 \%$ \\
\hline Curso técnico & 1 & $3,5 \%$ & Esquerda & 15 & $53,5 \%$ \\
\hline Terceiro grau & 12 & $42,8 \%$ & & & \\
\hline Mestrado & 6 & $21,4 \%$ & & & \\
\hline Total & 28 & $100 \%$ & Total & 28 & $100 \%$ \\
\hline
\end{tabular}

Quanto ao campo político, os entrevistados, mesmo quando filiados a partidos do campo ideológico da direita, não se declararam como sendo "de direita" e se posicionaram com sendo "de centro", ao contrário dos adeptos do campo da esquerda que rapidamente se identificaram como tal. Quanto ao grau de instrução formal, foi possível obter uma amostra ampla, mas o peso do terceiro grau e mestrado (juntos $64,2 \%$ ) no conjunto destaca o elevado grau de qualificação formal das elites locais. Vale a pena ser ressaltado que um dos prefeitos entrevistados concluiu recentemente um curso de gerente de cidade. 
A caracterização funcional dos entrevistados é relativamente complexa, pois uma pessoa que, por exemplo, hoje é um vereador, também é líder comunitário e membro de algum dos Conselhos Municipais, possivelmente em breve assumirá uma secretaria municipal, além de talvez já ter sido prefeito um dia. Dado o número reduzido de habitantes na maioria destes municípios, a elite local é composta por pessoas que freqüentemente se revezam nas funções públicas ao longo do tempo. Considerando esta ressalva, a Tabela 4 procura sintetizar as principais funções exercidas no momento da entrevista.

Tabela 4: Atual função pública exercida pelos entrevistados

\begin{tabular}{l|c|c}
\hline Função principal & 5 & $17,8 \%$ \\
\hline Vereador & 4 & $14,2 \%$ \\
\hline Secretário municipal & 3 & $10,7 \%$ \\
\hline Prefeito & 3 & $10,7 \%$ \\
\hline Extensionista agrícola (EMATER, ONG) & 3 & $10,7 \%$ \\
\hline Agente de extensão universitária & 2 & $7,1 \%$ \\
\hline Presidente de cooperativa de agricultores familiares & 2 & $7,1 \%$ \\
\hline Consultor (autônomo, SEBRAE) & 2 & $7,1 \%$ \\
\hline Presidente de associação comunitária & 2 & $7,1 \%$ \\
\hline Técnico do governo estadual & 1 & $3,5 \%$ \\
\hline Vice-prefeito & 1 & $3,5 \%$ \\
\hline Presidente de sindicato de trabalhadores rurais & 28 & $100 \%$ \\
\hline Total & & \\
\hline
\end{tabular}

Neste levantamento, o Poder Executivo municipal está representado por oito entrevistados (28,5\%), o Legislativo por cinco entrevistados $(17,8 \%)$, os representantes de classe e organizações da sociedade civil por seis entrevistados $(21,4 \%)$, e os técnicos e consultores de organizações diversas por nove entrevistados $(32,1 \%)$.

A entrevista foi composta por 29 perguntas abertas, que possibilitaram múltiplas respostas abarcando quatro blocos temáticos: a) Descentralização; b) Prefeitura; c) Câmara; e d) Conselhos municipais.

\section{1) A Descentralização}

Quanto ao primeiro tema, a descentralização, foram efetuadas sete perguntas, apresentadas a seguir de forma sintética.

1.1) Você acha que hoje o governo municipal decide mais que há 12 anos? Quais os exemplos de seu município você daria para ilustrar sua resposta? (apenas citações $>1$ ). 


\begin{tabular}{l|l|l|l}
\hline $21(75 \%)$ Sim, por exemplo: & & $7(25 \%)$ Não, ou pouco, pois: & \\
\hline Municipalização da saúde & 9 & Aumentou controle sobre executivo & 4 \\
\hline Maior profissionalismo na gestão local & 8 & Não foram dados recursos suficientes & 3 \\
\hline Descentralização da educação & 4 & & \\
\hline Maior apoio à agricultura familiar & 4 & & \\
\hline Maior controle pelo cidadão & 3 & & \\
\hline Aumento dos recursos disponíveis & 2 & & \\
\hline
\end{tabular}

Contrariando o amplo discurso sobre descentralização na literatura, identifica-se uma maioria, mas não um consenso, sobre o aumento do poder de decisão pelo governo local. Enquanto $75 \%$ dos entrevistados identificam hoje uma maior autonomia municipal, citando em primeiro lugar a municipalização da saúde como indicador para tal fato, $25 \%$ dos entrevistados não vêem maior autonomia no município, dado: a) o aumento dos controles, tanto pela legislação como pela população por meio dos Conselhos, e b) pela limitação dos recursos repassados. Todos os entrevistados que responderam "não" ou "pouco" pertencem ao campo político da esquerda.

1.2) Independente da legislação prever a descentralização, você é favorável à descentralização? Quais os benefícios? Quais os riscos? (apenas citações >1). As respostas foram unânimes no "sim".

\begin{tabular}{l|c|l|c}
\hline Benefícios da descentralização & & Riscos da descentralização & \\
\hline Maior conhecimento da realidade local & 11 & Repasse dos recursos é insuficiente & 13 \\
\hline $\begin{array}{l}\text { Maior fiscalização e controle } \\
\text { dos recursos }\end{array}$ & 9 & $\begin{array}{l}\text { Limitações da capacidade } \\
\text { técnica local }\end{array}$ & 11 \\
\hline $\begin{array}{l}\text { Maior proximidade entre } \\
\text { cidadão e governo }\end{array}$ & 9 & Não há riscos & 5 \\
\hline Facilita a administração & 8 & $\begin{array}{l}\text { Prefeiturização das } \\
\text { políticas públicas }\end{array}$ & 4 \\
\hline $\begin{array}{l}\text { Adequação e melhoria das } \\
\text { políticas públicas }\end{array}$ & 4 & $\begin{array}{l}\text { Riscos são menores que } \\
\text { na centralização }\end{array}$ & 3 \\
\hline
\end{tabular}

Constata-se uma posição amplamente favorável à ampliação da autonomia local, motivada principalmente pelo potencial de adequação das políticas públicas às condições específicas do município e a possibilidade de uma maior interação entre o setor público e a população, o que facilita o controle. Apesar das opiniões "não há riscos" ou "riscos são menores que na centralização" serem freqüentes, os principais fatores limitantes à autonomia do governo são identificados nas restrições impostas ao repasse de recursos financeiros e à fragilidade na capacidade operacional do governo local.

1.3) A participação das pessoas aumentou nos últimos anos em seu município? Por quê? (apenas citações > 4).

As respostas foram quase unânimes no "sim", com uma exceção, havendo entre os entrevistados divergências quanto ao ritmo deste aumento, 
pois para vários entrevistados, que se posicionaram no campo político da esquerda, a ampliação da participação é mais lenta do que deveria ser.

\begin{tabular}{l|c}
\hline Razões citadas para o aumento da participação popular & \\
\hline Ampliação do número de Conselhos municipais e credibilidade de suas ações & 14 \\
\hline $\begin{array}{l}\text { Ampliação da consciência crítica; maior cidadania; desejo de } \\
\text { controlar a corrupção }\end{array}$ & 10 \\
\hline Implantação do orçamento participativo estadual & 6 \\
\hline Ampliação da cobertura da mídia sobre desvio de recursos públicos & 5 \\
\hline
\end{tabular}

Constata-se um consenso de que houve uma sensível ampliação da mobilização e participação popular nos municípios da amostra. Como causas para este aumento da participação foram identificados dois eixos: por um lado, a criação de novos espaços públicos não estatais, os Conselhos e o orçamento participativo (20 citações), por outro, a mobilização social motivada principalmente pelo desejo de maior controle sobre a coisa pública (15 citações). Segundo um entrevistado, crítico à proliferação indiscriminada dos Conselhos, "a participação vem aumentando mesmo contra a vontade do cidadão".

\section{2) A Prefeitura}

Referente ao segundo tema, o Executivo municipal, foram feitas nove perguntas abertas, possibilitando múltiplas respostas, procurando identificar o modelo de prefeitura que o entrevistado defende e sua opinião sobre o desempenho atual.

2.1) Quais são os três principais problemas de seu município? Qual a capacidade de intervenção da prefeitura para lidar com eles? (apenas citações > 4).

\begin{tabular}{c|l|c}
\hline Ranking & Problemas & Citações \\
\hline 1 & $\begin{array}{l}\text { Poucas opções de renda no meio rural; produção } \\
\text { agrícola tem pouco valor; êxodo dos jovens do } \\
\text { meio rural; perda do investimento público feito } \\
\text { nos jovens. }\end{array}$ & 18 \\
\hline 2 & $\begin{array}{l}\text { Poucas opções de renda na sede do município; } \\
\text { desemprego; famílias vivem em miséria no } \\
\text { entorno da área urbana. }\end{array}$ & $\begin{array}{c}\text { Poluição do meio ambiente, da água em especial; } \\
\text { gestão inadequada do lixo; desgaste dos solos no } \\
\text { município; contaminação com agrotóxicos. }\end{array}$ \\
\hline
\end{tabular}




\begin{tabular}{|c|c|c|}
\hline 4 & $\begin{array}{l}\text { a) Ausência de saneamento; rede coletora limitada. } \\
\text { b) Ocupação desordenada; plano diretor não é } \\
\text { cumprido; falta planejamento urbano. } \\
\text { c) Atendimento de saúde pública insuficiente. }\end{array}$ & 7 \\
\hline 5 & $\begin{array}{l}\text { a) Educação pública de baixa qualidade; } \\
\text { inadequação do currículo para o meio rural. } \\
\text { b) Alto custo de implantação limita infra-estrutura } \\
\text { no meio rural, em especial estradas, telefone } \\
\text { e energia. }\end{array}$ & 6 \\
\hline 6 & $\begin{array}{l}\text { Qualificação limitada dos políticos; baixo profis- } \\
\text { sionalismo dos gestores públicos;autoritarismo. }\end{array}$ & 5 \\
\hline
\end{tabular}

Apesar da diversidade das experiências dos entrevistados, há uma convergência quanto às prioridades. As duas primeiras prioridades são relativas às limitações para melhoria da renda familiar, fato que está na raiz de uma série de outros problemas. Em terceiro lugar, está a percepção acerca do desgaste dos recursos naturais no município como um todo. Em quarto lugar, estão empatadas três prioridades referentes prioritariamente ao que é conhecido como "gestão urbana": saneamento, ocupação desordenada do solo e serviços de saúde. Em quinto lugar, estão empatadas a percepção sobre as deficiências na educação pública, em especial no meio rural, e a limitação econômica à universalização dos serviços públicos no meio rural. Em sexto lugar, a constatação de que a gestão local necessita de novos modelos e novos instrumentos.

Contrariando o nítido perfil de avaliação da capacidade do Executivo municipal, obtido em cidades de médio porte por Almeida e Carneiro (2000), nos municípios do meio rural, não foi constatado um consenso sobre qual a capacidade de intervenção da prefeitura. As respostas foram difusas e além disso identificadas com um governo específico: o atual ou o anterior. Não se verifica uma opinião formada sobre a capacidade da prefeitura que abstraia da administração atual ou da anterior.

A pergunta sobre o papel da prefeitura no município recebeu tantas respostas quantos os entrevistados, indicando que não existe um modelo consensuado sobre este aspecto. A solicitação de indicação de uma prefeitura que mereceria uma nota elevada praticamente não recebeu resposta, confirmando esta constatação. A Prefeitura de Porto Alegre foi citada seis vezes, com a justificativa de que esta tem planejamento e continuidade em suas ações. A solicitação de indicação de uma prefeitura conhecida por ser "ruim" também praticamente não teve resposta, mediante a justificativa de que o desempenho da prefeitura depende do prefeito em questão.

Como o período das entrevistas cobre o início de uma nova gestão municipal (administração 2001-2004), foi solicitado aos entrevistados que não participaram da gestão anterior a atribuição de uma nota à gestão 
dos últimos quatro anos. Não foi constatado um padrão nas respostas, indicando a ausência de parâmetros claros de avaliação da gestão municipal.

2.2) Nos próximos anos, o que deveria ser feito para melhorar o desempenho da prefeitura? (apenas citações > 4).

\begin{tabular}{c|l|c}
\hline Ranking & Sugestões & Citações \\
\hline 1 & $\begin{array}{l}\text { Qualificar o trabalho dos servidores; capacitação e } \\
\text { reciclagem funcional; seleção e contratação por concurso. }\end{array}$ & 17 \\
\hline 2 & $\begin{array}{l}\text { Adotar gestão profissionalizada; melhorar desempenho; } \\
\text { redução do autoritarismo do prefeito. }\end{array}$ & 15 \\
\hline 3 & $\begin{array}{l}\text { Introduzir visão e gestão de longo prazo; utilizar } \\
\text { planejamento e garantir continuidade. }\end{array}$ & 8 \\
\hline
\end{tabular}

A coleta de sugestões não resultou tão ampla e focada como a análise dos principais problemas do município (tópico 2.1), mas houve uma nítida concentração das respostas na profissionalização da gestão municipal, redução das arbitrariedades partidárias e a falta e continuidade nas políticas públicas.

2.3) Você conhece algum consórcio do qual o município participa? Qual?

Com relação ao consórcio, que potencialmente será cada vez mais um dos principais instrumentos de ampliação da capacidade operacional das prefeituras dos pequenos municípios, cerca de dois terços dos entrevistados souberam citar um, ou mais de um consórcio:

- consórcio de atendimento público de saúde por especialistas não cobertos pelo Sistema Único de Saúde (SUS);

- consórcio de máquinas para manutenção de estradas e obras no meio rural;

- consórcio para implantação de um programa regional de fruticultura;

- consórcio para manutenção de uma central regional de comercialização agrícola;

- consórcio para reciclagem de lixo; e

- consórcio de promoção do turismo regional.

Este quadro confirma os resultados do IBGE (2001), e de Brose (2000), acerca da expansão de consórcios intermunicipais, indica que o consórcio já constitui um instrumento razoavelmente conhecido e que sua utilização, tendencialmente mais freqüente, não deverá sofrer resistência por parte das elites locais.

\section{3) A Câmara}

Quanto ao terceiro tema, O Legislativo Municipal, foram feitas seis perguntas abertas, possibilitando múltiplas respostas, procurando identificar 
se existe um padrão claro sobre a função da Câmara Municipal na sociedade local e qual a avaliação que o entrevistado faz sobre a Câmara em seu município.

3.1) Na sua opinião, qual o papel da Câmara? Que nota você atribui a ela? Por quê?

De forma unânime, sem distinção de campo político, os entrevistados dividiram a sua resposta em duas partes. Primeiro citaram o papel da Câmara conforme previsto na legislação: legislar; fiscalizar o Executivo municipal; proporcionar o equilíbrio dos poderes e constituir-se no espaço de debate da sociedade local, a "casa do povo". Logo em seguida, porém, os entrevistados descreveram com indignação, mesmo aqueles que são vereadores, o papel da Câmara na prática: assistencialismo; auto-promoção dos vereadores; votação sem critérios técnicos, em especial o orçamento; submissão às orientações recebidas do prefeito; uso da tribuna para solicitar pequenas obras e consertos de ruas; oposição — quando existente — ao Executivo por razões ideológicas e não mediante debate de conteúdo; sessões enfadonhas e recheadas de fatos pitorescos/conflitos pessoais; vereador recebe em média $\mathrm{R} \$ 2.000,00$ por mês para freqüentar de uma a quatro sessões ordinárias noturnas por mês.

Dentre os 25 entrevistados que detalharam suas respostas sobre a Câmara, apenas dois souberam citar uma Câmara Municipal que, segundo eles, trabalha de forma adequada, explicando a citação pelo fato daquela Câmara "trabalhar em harmonia com a prefeitura". Dois entrevistados citaram a Câmara de Porto Alegre, "onde o Executivo não tem maioria, mas mesmo assim a cidade funciona, e o debate é mais técnico".

Como exemplos de Câmara que não funcionam adequadamente foram citadas as mais diversas, muitas vezes a Câmara do próprio município. As razões citadas para tanto: submissão ao Executivo; assistencialismo generalizado; compra de votos e intrigas pessoais.

3.2) Nos próximos anos, o que deve ser feito para aperfeiçoar o desempenho da Câmara? (apenas citações >4).

\begin{tabular}{c|l|c}
\hline Ranking & Sugestões & Citações \\
\hline 1 & $\begin{array}{l}\text { Reduzir subsídios e o número de viagens dos } \\
\text { vereadores; vereador não deve ser profissão, mas } \\
\text { trabalho comunitário. }\end{array}$ & 18 \\
\hline 2 & $\begin{array}{l}\text { Capacitar vereadores, de preferência ainda } \\
\text { quando candidatos. }\end{array}$ & 11 \\
\hline 3 & $\begin{array}{l}\text { Fechar a Câmara e transferir suas funções para } \\
\text { os conselhos municipais, com conselheiros } \\
\text { não remunerados. }\end{array}$ & 10 \\
\hline 4 & Capacitar os assessores dos vereadores. & 8 \\
\hline
\end{tabular}




\begin{tabular}{c|l|c} 
(continuação) & \multicolumn{2}{l}{} \\
\hline 5 & $\begin{array}{l}\text { Os vereadores devem ouvir mais o povo, e } \\
\text { os eleitores devem estar presentes nas sessões } \\
\text { da câmara. }\end{array}$ & 7 \\
\hline 6 & $\begin{array}{l}\text { A população deve votar de forma mais consciente; } \\
\text { o voto não deve ser uma troca de favores ou } \\
\text { comprado. }\end{array}$ & 6 \\
\hline 7 & $\begin{array}{l}\text { A Câmara deve ter uma postura pró-ativa; pensar } \\
\text { o município como um todo; desenvolver uma } \\
\text { visão de futuro e estratégias de desenvolvimento. }\end{array}$ \\
\hline
\end{tabular}

Identificou-se uma ampla insatisfação com o desempenho da Câmara de tal ordem, que $36 \%$ dos entrevistados propõem o fechamento da mesma. Mesmo que teoricamente as funções do Legislativo sejam conhecidas pela elite local, 36\% dos entrevistados acreditam que os Conselhos municipais poderiam assumir a função prevista para os vereadores.

A Câmara Municipal, mesmo do ponto de vista dos vereadores entrevistados, é percebida como essencialmente corrupta, manipulada pelo Executivo e presa a interesses pessoais. A compra de votos parece ser rotineira e representa um investimento a ser recuperado futuramente por meio dos subsídios, de diárias e da troca de favores diversos.

As proposições de melhoria podem ser agrupadas em dois eixos:

a) transformar a função legislativa em um trabalho comunitário - a exemplo dos conselheiros — qualificando as pessoas para esta função; e

b) ampliar a interação e o controle da sociedade civil com o Legislativo municipal.

\section{4) Os Conselhos}

Sobre o quarto tema abrangido pela entrevista, os Conselhos municipais, foram feitas sete perguntas similares às feitas sobre a Câmara, procurando identificar a existência de uma opinião formada sobre esta inovação recente do governo local.

4.1) Na sua opinião, qual o papel do Conselho municipal?

Todos os entrevistados responderam de forma bastante similar, utilizando conceitos como: encaminhar as demandas de baixo para cima; fiscalizar o Executivo; defender segmentos da sociedade muitas vezes esquecidos; garantir políticas públicas melhores; possibilitar a participação da sociedade e focalizar as políticas públicas.

Constata-se uma percepção quase unanimamente positiva, inclusive pelos representantes da prefeitura, quanto aos Conselhos. Seu papel complementar ao Executivo municipal é visto no sentido de permitir a inserção da opinião e dos interesses de determinados segmentos sociais no policy cicle, desta forma contribuindo para o aperfeiçoamento das 
políticas públicas. Não se confirmou o quadro apresentado para Santa Catarina por Comassetto (2000), onde o levantamento identificou uma visão essencialmente negativa sobre os Conselhos. Aparentemente os Conselhos têm cumprido o importante papel de escola de democracia e de consolidação de novos espaços públicos.

4.2) Quais os Conselhos existentes em seu município? Como eles funcionam?

\begin{tabular}{l|l}
\hline \multicolumn{2}{l}{ Conselhos municipais identificados (todas citações) } \\
\hline 01 Conselho da mulher & 11 Conselho do meio-ambiente \\
\hline 02 Conselho da Criança e do Adolescente & 12 Comissão municipal do emprego \\
\hline 03 Conselho do idoso & 13 Conselho da merenda escolar \\
\hline 04 Conselho da agropecuária & 14 Conselho de trânsito \\
\hline 05 Conselho da saúde & 15 Conselho de assistência social \\
\hline 06 Conselho da segurança & 16 Conselho de turismo \\
\hline 07 Conselho da educação & 17 Conselho tutelar \\
\hline 08 Conselho da cultura & 18 Conselho do esporte \\
\hline 09 Conselho das etnias & 19 Conselho da habitação \\
\hline 10 Conselhos distritais & 20 Conselho do desenvolvimento \\
\hline
\end{tabular}

Os Conselhos identificados como "bons" pelos entrevistados foram caracterizados como: têm história; são atuantes; há reuniões regulares e ativas; existe um debate técnico; integrantes representam diferentes organizações; e há participação ativa dos conselheiros.

Os Conselhos identificados como "ruins" foram adjetivados como: quase não há conselheiros jovens; presidente do Conselho é centralizador; baixa representatividade; comandado pela prefeitura; não há renovação; e há cooptação pelo prefeito.

Foram identificados 20 Conselhos setoriais diferentes que funcionam nos 15 municípios visitados. Enquanto o levantamento do IBGE (2001) identifica uma média de 4,9 Conselhos por município, foram identificados para os municípios de caráter rural visitados uma média de oito Conselhos por município. Se por um lado este resultado indica uma considerável ampliação da participação popular ocorrida na última década, por outro lado o fraco desempenho de boa parte dos Conselhos indica as limitações. Os Conselhos não surgiram a partir de uma mobilização da sociedade local, mas foram criados por exigência de políticas estaduais e federais e recriam no município a fragmentação existente nas outras esferas do Estado.

Os principais problemas apontados pelos entrevistados se referem ao fraco desempenho de muitos Conselhos que "só existem no papel", o fato de que um reduzido grupo de lideranças comunitárias acaba por participar de vários Conselhos ao mesmo tempo, dado que os conselheiros enfrentam um custo alto em termos de tempo e deslocamentos, que não 
são ressarcidos, limitando o número de pessoas que se dispõe a ocupar as vagas. Sem falar na freqüente manipulação pelo Executivo e a falta de informação e capacitação dos conselheiros.

Apesar do otimismo com relação aos Conselhos, já se notam os primeiros sinais de desgaste. Vários entrevistados frisaram a proliferação excessiva de Conselhos municipais. Em um município, foi relatado que o recém-criado Programa Federal de Bolsa-Escola queria criar um Conselho específico, mas encontrou resistência por parte das lideranças locais. Os técnicos do programa acabaram por aceitar que a responsabilidade fosse delegada ao Conselho Municipal de Educação.

4.3) Nos próximos anos, o que deve ser feito para aperfeiçoar o desempenho dos Conselhos? (citações >4).

\begin{tabular}{c|l|c}
\hline Ranking & Sugestões & Citações \\
\hline 1 & $\begin{array}{l}\text { Escolha dos conselheiros sem critérios partidários; } \\
\text { maior representatividade na composição; evitar troca } \\
\text { dos conselheiros a cada troca do prefeito. }\end{array}$ & 14 \\
\hline 2 & $\begin{array}{l}\text { Capacitar os conselheiros para exercerem o seu } \\
\text { papel de forma ativa. }\end{array}$ & 12 \\
\hline 3 & $\begin{array}{l}\text { Caráter deliberativo ao Conselho; ter papel formulador } \\
\text { de políticas públicas. }\end{array}$ & 10 \\
\hline 4 & Tornar os Conselhos independentes da prefeitura. & 7 \\
\hline 5 & $\begin{array}{l}\text { Integrar Conselhos que tratam do mesmo setor; criar } \\
\text { conselhos microregionais para determinados temas. }\end{array}$ & 6 \\
\hline 6 & $\begin{array}{l}\text { Conceder ajuda de custo aos conselheiros; garantir } \\
\text { assessoria técnica independente aos conselheiros. }\end{array}$ & 5 \\
\hline
\end{tabular}

Com exceção da proposta citada em quinto lugar, todas as propostas possuem um elemento em comum: o desejo de maior autonomia dos Conselhos em relação ao Executivo municipal. A proposta citada em quarto lugar prevê inclusive a completa separação dos Conselhos da prefeitura. Se por um lado este quadro indica as limitações que os conselheiros enfrentam para cumprirem com seu papel e a resistência demonstrada pelas prefeituras em delegar a alocação dos recursos, por outro lado este quadro confirma a postura positiva em relação aos Conselhos. Mesmo que revele uma lacuna no conhecimento acerca do caráter jurídico dos Conselhos municipais.

Por definição, os Conselhos municipais são instâncias auxiliares ao Executivo, por este criados mediante decreto ou projeto de lei. $\mathrm{O}$ fato de vários prefeitos cometerem o erro de trocar conselheiros quando assumem seu mandato não autoriza a busca pela solução simples da autonomia dos Conselhos. Se os Conselhos devem ser autônomos, como proposto majoritariamente pelos entrevistados do campo político da esquerda, então eles deixam de ser Conselhos municipais para se tornarem Conselhos populares, criados pela vontade de seus integrantes e não por ato do 
executivo. "Conselhos populares, por serem dotados de autonomia não são subordinados à Administração Municipal como os Conselhos Municipais." (Saule Jr., 1997: 268). Porém, os Conselhos populares não podem ter caráter deliberativo, não podem decidir sobre recursos públicos e se assemelham mais ao Legislativo do que ao Executivo.

\section{Proposições}

"O sentimento de moralidade que contagiou o Senado não é resultante de uma mudança no seu próprio interior. Vem de fora para dentro. O que mudou foi o cidadão."

Geraldo Althoff, presidente do Senado, em 9 de agosto de 2001, sobre o caso do senador Jader Barbalho.

Iniciamos este trabalho com a indagação: Como aperfeiçoar os governos locais de pequenos municípios gaúchos para que estes cumpram as promessas da descentralização — maior eficácia, eficiência e eqüidade? Procuramos por causas e limitantes do desempenho do governo local:

a) no atual processo de descentralização em curso no país;

b) na evolução histórica do município brasileiro; e

c) nas especificidades dos municípios gaúchos.

Uma pesquisa de campo limitada a 15 municípios nos forneceu elementos para um diagnóstico dos principais problemas enfrentados pelo governo local — entendido governo local como o tripé formado por Prefeitura, Câmara e Conselhos - em municípios rurais. E buscamos ao longo desta análise por proposições para uma intervenção organizada, de impacto sustentável e abrangente.

De acordo com um estudo transversal em seis países, realizado por Hildebrand e Grindle (1997), o aumento da capacidade de boa governança não advém simplesmente da realização de um curso para servidores públicos ou da compra de um computador para a repartição, o enfoque tradicional de fortalecimento institucional. As duas autoras apresentam um marco referencial sistêmico com o propósito de aumento da capacidade de desempenho do setor público que vá além da realização de cursos e que será utilizado a seguir para a sistematização das proposições.

A partir do enfoque sistêmico, o objetivo maior para o fortalecimento dos governos locais deve consistir no estabelecimento de uma cultura e prática cotidiana marcadas pela flexibilidade; capacidade de identificação e solução de novos problemas; trabalho em equipe; participação popular; ética e profissionalismo na gestão em todo o município, e não apenas na prefeitura. Extrapolando o minimalismo da manutenção de mecanismos democráticos formalizados e alterando o tecido cultural e político no qual 
o município está inserido. Pois, segundo Arretche (1996: 48), "não é suficiente que se reforme apenas a escala ou o âmbito da esfera responsável pela decisão a ser tomada. É necessário que se construam instituições cuja natureza e cujas formas específicas de funcionamento sejam compatíveis com os princípios democráticos".

O referencial proposto por Hildebrand e Grindle é composto por cinco dimensões:

- o ambiente de ação — definido como o meio econômico, político e social no qual o governo está imerso; intervenções no ambiente de ação produzem resultados apenas a longo prazo, pois buscam alterar condicionantes estruturais da economia, da política e da sociedade;

- o contexto institucional - composto pelas normas e regras estabelecidas para o setor público, o orçamento disponível, as responsabilidades do governo, as políticas públicas concorrentes e a estrutura do Estado;

- a rede de trabalho - composta pelo conjunto de organizações envolvidas em uma mesma área de atuação; cada rede pode ser composta por diferentes tipos de organizações;

- a organização - definida pelas suas estruturas internas, processos, recursos e gestão, que condicionam os objetivos, missão e cultura organizacional; e

- os recursos humanos da organização - a forma como os servidores públicos são formados, contratados, remunerados e mantidos em sua carreira tem um impacto profundo na capacidade de desempenho do setor público.

Estas cinco dimensões estão integradas e se influenciam mutuamente, condicionando a capacidade de desempenho do governo (para um enfoque mais amplo veja, por exemplo, Azfar, Kähkönen e Meagher, 2001).

A estratégia aqui proposta se compõe de dois eixos principais: a profissionalização do governo local, visando o aumento de sua capacidade operacional, e a ampliação do aumento da capacidade de controle por parte da sociedade local. Não se pretende que esta seja uma proposta isenta de conflito, mas o federalismo constitui um arranjo institucional desenhado para acomodar o conflito e viabilizar soluções diversificadas para o mesmo.

\section{A dimensão dos recursos humanos}

Freqüentemente, os servidores de governos locais reclamam que seu trabalho não é relevante, que suas habilidades são subutilizadas e que a qualidade de seu desempenho não tem influência em sua carreira. Segundo o levantamento do IBGE (2001), 50\% dos municípios têm no máximo 300 
funcionários, e $70 \%$ têm no máximo 500 funcionários. Estamos tratando, portanto, de um universo bem delimitado.

Persiste ainda em nossa sociedade a idéia de que ocupar estes cargos no governo local não exige qualquer tipo de qualificação específica. Citando um slogan de venda de eletrodoméstico: "não requer prática nem habilidade, toda criança é capaz", esta idéia está presente em todos os campos políticos, e assim que um partido assume uma prefeitura, assistese a uma troca generalizada dos ocupantes dos cargos não-concursados. Funcionários concursados que são identificados como pertences à oposição são transferidos e relegados ao ostracismo em postos de trabalho afastados.

Este procedimento é danoso em vários aspectos: impede-se o aprendizado organizacional; não há gestão do conhecimento; a continuidade das políticas públicas torna-se praticamente impossível e grande parte dos quatro anos de uma gestão é gasta para "aprender o serviço" em experimentos sem acompanhamento e sem consistência. $\mathrm{O}$ alto grau de amadorismo e a falta de continuidade na gestão pública já eram registrados como problemas estruturais pela US Operations Mission to Brazil nos anos 50 (Friedmann, 1960).

A nova Lei de Responsabilidade Fiscal vem reforçar uma luta iniciada nos anos 30: o ingresso no serviço público apenas mediante concurso. Mas este é apenas o primeiro passo. Além da contratação por mérito e não por filiação partidária, é necessário introduzir nas prefeituras a gestão estratégica de recursos humanos. A partir da definição de uma visão, são definidos objetivos estratégicos, que permitem a definição de objetivos para as unidades organizacionais e a definição de objetivos para cada servidor, registrados em uma descrição de função individual. Esta sistemática - que deve funcionar independentemente do partido que estiver governando no momento - constitui a base para avaliações de desempenho em intervalos regulares, para o planejamento de capacitação e reciclagem periódicos, bem como o enquadramento no plano de cargos e salários.

Contudo, é necessária também uma etapa anterior: a formação de recursos humanos. A complexidade atual, e futura, do governo local não permite mais a gestão pública baseada nas tradições ou em reportagens da televisão. Os servidores das prefeituras, os assessores dos vereadores, os conselheiros municipais, os conselheiros do orçamento participativo - para citar os principais grupos envolvidos com esta situação — não dispõem no Rio Grande do Sul de uma instância que lhes ofereçam capacitação, formação e reciclagem de modo sistemático. Cada um "vai se virando como pode" ao assumir sua função. Tanto que no atual programa de capacitação das prefeituras gaúchas em gestão ambiental, a Secretaria Estadual do Meio Ambiente se viu obrigada a trazer consultores do IBAMA do Rio de Janeiro para ministrar os cursos. Torna-se urgente disponibilizar no Rio Grande do Sul uma oferta continuada e regular de formação 
especializada para atuação na gestão pública local, por meio de cursos modulados, complementados pela produção de publicações, disponibilização de informações na Internet e acompanhamento pós-curso mediante o conceito de aprendizado continuado.

\section{A dimensão da organização}

A gestão no governo local precisa ser profissionalizada. $O$ primeiro passo consiste no estabelecimento de uma qualificação para prefeitos, secretários municipais, conselheiros e vereadores que estabeleça um patamar mínimo de qualidade e informação nos processos de decisão. O prefeito tem que deixar de se preocupar com o parafuso da retroescavadeira e passar a analisar os cenários possíveis do futuro do município, iniciando hoje as ações necessárias para concretizar este futuro almejado no amanhã.

A partir deste novo patamar de ação, deve ser estabelecida uma assessoria técnica continuada à prefeitura para a sistematização de procedimentos, estabelecimento de parâmetros de avaliação de desempenho e definição de planos estratégicos de forma participativa, envolvendo a comunidade. Com esta base, é possível proceder a uma "certificação de qualidade" da prefeitura que envolva as dimensões da participação e da transparência, sob responsabilidade de auditoria regular, por exemplo, do Tribunal de Contas. No Estado de São Paulo, uma ação deste tipo foi iniciada pela Assembléia Legislativa (SEADE, 2001).

Tendo sido estabelecido um patamar mínimo de organização e qualidade na prefeitura, o próximo passo deve consistir na ampliação da arrecadação própria, tendo em vista que a excessiva dependência das pequenas prefeituras das transferências pelos governos estaduais e federal não só restringe a possibilidade de ação efetiva como limita a autonomia municipal. Sendo o município um ente federativo, não cabe mais a peregrinação dos prefeitos pelas capitais à busca de recursos ou a submissão a um deputado apenas para se obter acesso aos programas especiais do Governo Federal.

$\mathrm{O}$ aumento da arrecadação própria da prefeitura sofre severas limitações pela estrutura fiscal brasileira, e freqüentemente se resume ao ISS e IPTU. Propõe-se ampliar a arrecadação em três etapas para a utilização plena do potencial de arrecadação previsto pela legislação:

- na primeira etapa, o cadastro urbano e a planta de valores devem ser informatizados e atualizados, como base para a implantação de uma gestão profissionalizada de fiscalização, arrecadação, gestão da cobrança e de dívida ativa dos principais impostos municipais (veja FGV/EAESP, 2000);

- em uma etapa seguinte, é necessário ampliar a arrecadação do imposto que deveria ser a base da arrecadação municipal, mas que por 
razões históricas é um dos mais sonegados e mal administrados do país: o Imposto Territorial Rural — ITR (Costa, 1996; Saule Jr., 1997), baseado até hoje na concepção do Direito português do tempo das sesmarias; a lei no 10.267, de 29 de agosto de 2001, cria o Cadastro Nacional de Imóveis Rurais (CNIR), que pretende alterar profundamente a forma de registro de imóveis rurais pelo Sistema Geodésico Brasileiro e ampliar o controle sobre os cartórios de registro de imóveis, fornecendo às prefeituras uma nova base para avaliação e tributação dos imóveis rurais; e

- na terceira etapa, pode ser introduzida e ampliada a cobrança da taxa de melhoria, praticada por enquanto em pequenos municípios principalmente no Paraná (veja OED, 1998; 2001).

Esta ampliação da arrecadação, já prevista na legislação, pode ser operacionalizada pelas prefeituras, entre outros, com o apoio do Programa de Modernização da Administração Tributária — PMAT (BNDES b, 2001). Adicionalmente, é possível estudar novas formas de arrecadação própria para os governos municipais. Na Europa, está em expansão a produção e comercialização, em nível municipal, de energia a partir de fontes renováveis (vento e biomassa), permitindo a pequenos municípios não apenas a auto-suficiência em energia como uma nova fonte de arrecadação pela venda de energia de fontes não-poluentes.

Além da organização e profissionalização do Executivo, mais urgente ainda é a Modernização da Câmara Municipal. Esta deve deixar de ser a "vergonha da democracia" para se tornar o fórum popular pensante no município. Os instrumentos formais para tal existem, falta utilizá-los neste sentido. Para tanto é necessário evoluir do atual debate em que se defende o embate entre a democracia direta e a representativa. "É um erro opor participação e representação. Elas formam um par indissociável, com base numa idéia fundamental: a de uma soberania ascendente." (Viveret, 2001).

Os vereadores podem utilizar sua autonomia e acesso à informações para liderarem o processo de planejamento estratégico do município, estabelecendo visões e cenários de futuro que incluam o debate ativo e permanente com a comunidade e se operacionalize na definição dos Planos Plurianuais (PPAs) e Lei de Diretrizes Orçamentárias (LDOs). Isto exige não só a qualificação dos vereadores e seus assessores como a definição de uma nova missão para a Câmara. Por que as Câmaras não podem começar a liderar o processo de orçamento participativo no município?

As Câmaras detêm o potencial ainda inexplorado de transformarem os PPAs e as LDOs em instrumentos de gestão, controle e avaliação da atuação do Executivo no município. De forma complementar, podese desenhar uma nova geração de programas federais voltados não 
apenas ao "financiamento da pobreza", mas também focados no financiamento e apoio a inovações em nível local, de modo integrado à gestão pela Câmara.

Um primeiro passo nesse sentido pode consistir na capacitação dos atores locais, em especial Câmara e Conselhos, na avaliação de desempenho de programas públicos. Um exemplo simples consiste nos diversos convênios e contratos de gestão que toda prefeitura firma ao longo do tempo, com a Associação de Municípios, com a EMATER, com a Companhia de Água e Saneamento, com o SEBRAE etc., e que via de regra não contêm uma definição dos indicadores de desempenho, inviabilizando o controle e a avaliação por parte da Câmara e/ou pelos Conselhos municipais.

É necessário ainda interromper o processo de proliferação de Conselhos municipais por exigência dos governos federal e estadual, e conduzir um processo de definição estratégica interna ao município sobre "O que são?" e "Para que servem?" os Conselhos municipais, bem como os Conselhos populares. A partir desta definição é possível estabelecer um debate público a partir do ponto de vista da estratégia municipal, de quais e quantos Conselhos municipais são necessários. É possível imaginar um modelo no qual se crie um Conselho municipal de desenvolvimento unificado para o município, amplamente representativo, que para a assessoria específica ao Executivo crie comissões setoriais.

Adicionalmente, é necessária a qualificação do trabalho dos conselheiros com base em quatro áreas de ação: assegurar em conjunto com o Executivo e o Legislativo que haja continuidade na ocupação dos cargos; seleção dos conselheiros por eleição na comunidade; oferta de qualificação aos conselheiros; e acompanhamento técnico permanente aos conselheiros. A participação é crucial para o êxito do governo local (Reid, 2000), mas ela deve ser qualificada, por exemplo, capacitando conselheiros em monitoria e avaliação de políticas públicas (Sangra, 2000).

\section{A dimensão da rede setorial}

A assessoria às Prefeituras no Rio Grande do Sul foi em grande parte privatizada e geralmente se limita aos aspectos jurídicos/contábeis. Cada prefeito contrata empresas de consultoria conforme o seu grau de conhecimento sobre as áreas de trabalho. Por outro lado existem vários núcleos de pesquisa e produção de conhecimento sobre gestão local dispersos pelo Estado, em especial junto às universidades. Existe assim o potencial de criação de uma rede de formação e assessoria em gestão municipal que cubra todo o Estado, integrando núcleos universitários, organizações do terceiro setor, consultorias, Tribunal de Contas, FAMURS e Assembléia Legislativa na prestação de serviços padronizados e integrados às prefeituras. O núcleo animador desta rede deveria ser criado 
fora da esfera do governo estadual para evitar ingerências partidárias e garantir continuidade de ação.

Com a nova Lei de Responsabilidade Fiscal, fica impossibilitado o financiamento direto de investimentos nos municípios pelas outras esferas de governo. Tornou-se assim urgente o estabelecimento de um novo sistema de financiamento para os municípios, que por meio de uma gestão profissionalizada ofereça juros baixos e prazos longos adequados às especificidades do crédito necessário para investimentos públicos municipais (veja Paranacidade, 2001). Existe o potencial de criação de um banco municipal no Rio Grande do Sul a partir do capital do Programa Integrado de Melhoria Social (FUNDOPIMES), oportunidade que poucos Estados da Federação possuem. A significativa experiência do Fundo para o Desenvolvimento da Bacia do Prata (FONPLATA) na região (Gazeta Mercantil, 2001) pode servir de referência para a tecnologia financeira a ser utilizada. Esta nova instituição deveria financiar não apenas obras, mas de igual importância é o financiamento de projetos multissetoriais (BNDES a, 2001).

Mesmo gozando de ampla autonomia, as prefeituras dos pequenos municípios dependem em larga escala do conhecimento acumulado na estrutura dos governos estaduais. Porém, é necessário promover uma mudança cultural junto ao corpo técnico dos governos estaduais no sentido de que as administrações municipais não sejam vistas com desdém pelo corpo burocrático lotado na capital.

“Capacitar as prefeituras dos 467 municípios do Estado é um processo muito longo, caro, que não dá retorno nenhum para o governo atual no período dos quatro anos de gestão. Por que o governo estadual faria isto? É também uma questão política. As prefeituras são na maioria de outro partido. Além disso, a gente capacita os técnicos das prefeituras e eles não são concursados, eles saem com a troca do governo e aí entram novos. Se o governo do estado quer aperfeiçoar administrações municipais, tem que escolher aquelas que interessam, que interessam ao atual plano de governo. Não dá para fazer para todos."

(Depoimento espontâneo de uma técnica da Secretaria Estadual de Planejamento do Rio Grande do Sul, durante reunião para elaboração de um programa de fortalecimento da gestão urbana nos municípios do interior).

\section{A dimensão do contexto institucional}

Para o desenvolvimento da capacidade de desempenho dos governos 
as três esferas de governo. Os governos federal e estadual vêm delegando aos municípios de forma aleatória atribuições e responsabilidades sem o repasse de know how e recursos para cumprir com tais tarefas, e sem mencionar a baixa capacidade operacional dos pequenos municípios. É fundamental a negociação de uma legislação que delimite com clareza as atribuições de cada esfera e limite a contínua sobrecarga, em especial, das prefeituras do meio rural, definindo fontes de financiamento e receitas próprias (Lagemann e Bordin, 1993).

Adicionalmente, torna-se urgente a limitação da criação de novos municípios cada vez menores. É necessário estabelecer critérios rigorosos que dificultem a emancipação e, ao invés disto, estimular e premiar a formação de consórcios intermunicipais que dêem escala, qualidade e uma relação de custo/benefício positiva a uma série de serviços públicos como: saúde, gestão de resíduos sólidos, manutenção de estradas vicinais, saneamento básico e manejo de bacias hidrográficas (Cruz, 2001).

Para evitar a proliferação da perigosa tendência do desejo de fechamento das Câmaras, além da qualificação e reorganização da atuação dos vereadores, se faz necessário estabelecer um horizonte para a eliminação, ou pelo menos, a significativa redução dos subsídios pagos ao vereador. Para qualificar a atividade legislativa municipal, esta deve ser percebida como trabalho comunitário e não como fonte de enriquecimento pessoal ou "caixinha" partidária. Uma legislação específica pode estabelecer uma redução lenta e gradual ao longo de vários anos do teto dos subsídios pagos pelo Legislativo. No Estado de São Paulo, já existe o primeiro município no qual a vereança é um trabalho voluntário.

\section{A dimensão do ambiente de ação}

A mudança cultural pretendida aqui demanda o início de ações que produzem resultados apenas a longo prazo, na formação e ampliação de capital social (Baron et al., 2000). Um dos principais elementos consiste na ampliação do acesso à informação pelo cidadão. Neste contexto, cabe papel fundamental à melhoria da qualidade do ensino público, que atualmente compromete o potencial de melhoria do desempenho dos governos locais. Uma qualificação mais abrangente do cidadão é necessária para que seja possível passar da atual discussão de alocação de investimentos "Onde construir o posto de saúde?" - para um debate qualificado sobre a ação pública — "Que tipo de saúde pública nós queremos?”.

Especialmente no ensino médio, o currículo deve ser ampliado pela introdução de noções básicas de cidadania, gestão pública e controle social para que o cidadão disponha de conhecimentos básicos para analisar e avaliar com maior propriedade o setor público (Brüning, 1995). Esta demanda não é nova. Já registrava Guimarães (1904: 59): “A falta de 
educação nem só à industria e à agricultura tem prejudicado: ao comércio tem causado iguais danos."

Para os adultos, urge a criação de uma rede de formação em cidadania, que pode ser estabelecida a partir da rede de ONGs existentes no Estado, tornando acessível ao cidadão cursos modulados, material informativo e assessoria técnica no que concerne à atuação da prefeitura, do Legislativo e dos Conselhos municipais (Kraft, 1995). O núcleo de animação desta rede deveria ser criado fora do governo estadual e trabalhar em estreita vinculação com o Tribunal Eleitoral, o Tribunal de Contas, União dos Vereadores e a Assembléia Legislativa. O cidadão não tem como acompanhar o orçamento, avaliar resultados, demandar desempenho, se não estiver devidamente qualificado e informado (Songco, 2001).

Em uma segunda etapa, esta rede de formação da cidadania pode estabelecer uma assessoria permanente junto à mídia regional e local no sentido de qualificar a cobertura acerca da gestão pública local. Possibilitando uma transição da cultura de relatar escândalos para uma cultura de divulgar avaliações e análises críticas. Além de oferecer cursos rápidos e encontros regulares a jornalistas e editores, é possível oferecer informação especializada à mídia, tal como a UNICEF promove com relação à infância.

\section{Conclusão}

Parafraseando Costa (1997), defender uma política específica para os pequenos municípios de caráter rural constitui tarefa tão promissora quanto ingrata. A inexistência de uma tradição de estudos e análises focadas em municípios rurais dificulta a analogia, as inferências e a generalização de recomendações feitas majoritariamente para os grandes aglomerados urbanos do ponto de vista da arquitetura e urbanismo, demandando a definição não apenas de um marco teórico próprio como a expansão de uma consciência acerca das diferenças existentes entre as diversas categorias de municípios.

Além disso, deve se disseminar a consciência de que o município continua sendo, após cerca de 7.000 anos de civilização, o mais próximo que chegamos do ideal democrático do autogoverno. A desconfiança detectada no âmbito da pesquisa efetuada no meio rural gaúcho quanto à legitimidade de instâncias representativas é antiga. Crises de representatividade vêm se repetindo desde o século XVIII, quando a escolha por sorteio - e não por voto - ainda era vista como mais democrática (Manin, 1995). Além disso, deve ser divulgado que: "Para quem pensa que o Parlamento brasileiro é acidente, aqui vão dados importantes: é o terceiro mais antigo do mundo em funcionamento contínuo, perdendo em longevidade apenas para a Inglaterra e o dos EUA (...) O milagre dessa continuidade é tão mal explicado como o próprio país.” (Freitas, 2001: 93). 
O fortalecimento do desempenho dos governos locais deve se dar a

partir da experiência centralizadora no Brasil, onde o governo central sempre foi capaz de inovações institucionais e de responder às pressões advindas das mudanças na sociedade. Os governos locais, formados por Prefeitura, Câmara e Conselhos, precisam ser dotados da mesma capacidade.

\section{Referências bibliográficas}

ABERs, Rebbeca. (2000), Inventing Local Democracy: Grassroots Politics in Brazil. Boulder: Lynne Riemer.

Abramovay, Ricardo. (2000), "Funções e medidas da ruralidade no desenvolvimento contemporâneo". Textos para Discussão $n^{\underline{o}} 702$, Rio de Janeiro: IPEA.

Affonso, Rui; Silva, Pedro (orgs.). (1994), Descentralização e Políticas Sociais. Projeto Balanço e Perspectivas do Federalismo Fiscal no Brasil. São Paulo: FUNDAP. (http://www.fundap.sp.gov.br/info/fed4.htm).

Afonso, José. (1996), "Descentralizar e depois estabilizar: a complexa experiência brasileira". Revista do BNDES, Rio de Janeiro, vol. 3(5), p. 31-62, junho.

Almeida, Maria; CARneIro, Leandro. (2000), “The New Local Agenda: Elite Support for Decentralization of Social Services in Brazil". Paper apresentado no IPSA Congress, Quebec, agosto. (http://www.fapesp.br/human50.htm).

Arretche, Marta. (1996), "Mitos da descentralização. Mais democracia e eficiência nas políticas públicas?”. Revista Brasileira de Ciências Sociais, São Paulo, vol. 31(11), p. 44-66, junho.

Assis, José. (1984), “Os mandarins da República: anatomia dos escândalos na administração pública de 1968-84”. Coleção Estudos Brasileiros 75, Rio de Janeiro: Paz e Terra.

Aureliano, Liana. (1996), "Descentralização de políticas sociais: alguns exemplos da saúde, educação e assistência”, in Jung, Winfried (org.), Poder local face às eleições de 1996. Série Debates no 10. São Paulo: Fundação Konrad Adenauer.

AzFAr, Omar; KäHKönen, Satu; MeAgher, Patrick. (2001), Conditions for Effective Decentralized Governance: A Synthesis of Research Findings. University of Maryland. (http://www1.worldbank.org/publicsector/decentralization/synthesispaper.pdf).

Baron, Stephen; Field, John; Schuller, Tom (eds.). (2000), Social Capital. Critical Perspectives. Oxford: Oxford University Press.

Bndes (a). Projeto multisetorial integrado. Acessado 26.6.2001. (http://www.bndes.gov.br/ atuar/multiset.htm)

Bndes (b). Programa de Modernização da Administração Tributária. Acessado 26.6.2001 (http://www.bndes.gov.br/atuar/municip.htm).

Bndes. SeCretaria Para Assuntos Fiscais. (2000), Sistemas de crédito local: o que ensinam as experiências internacionais. Boletim Informe-se no13, maio.

. (2001), Ações Sociais Básicas: descentralização ou municipalização?. Boletim Informe-se no 23, janeiro.

(2001), Receita municipal: a importância das transferências do FPM e do SUS. Boletim Informe-se no 28 , junho. 
Bovo, José. (2001), “Gastos sociais dos municípios e desequilíbrio financeiro". Revista de Administração Pública, Rio de Janeiro, vol. 35(1), p. 93-117, jan./fev.

Brasil. Ministério do Planejamento e CoordenaÇão Geral. (1969), Reforma administrativa em marcha. Relatório das atividades em 1967 e 1968. Rio de Janeiro: Escritório da Reforma Administrativa.

Brasil. Senado Federal. (1976), Leis Orgânicas dos Municípios. Brasília. do Senado.

Brose, Markus. (2000), Fortalecendo a democracia e o desenvolvimento local:103 experiências inovadoras no meio rural gaúcho. Santa Cruz: EDUNISC/GTZ.

BRÜNING, Paulino. (1995), A fiscalização do município pelos vereadores. Manual de orientação. Blumenau: Editora FURB.

Carneiro, Levi. (1931), Problemas municipais. Rio de Janeiro: Alba.

CAstro, José. (1999), Direito municipal positivo. Belo Horizonte: Ed. Del Rey.

CERRI, Claudio. (2001), "O chão do amanhã. Colapso urbano leva prefeitos a incorporar o entorno rural no planejamento do futuro". Revista Globo Rural, ano 17(192), p. 48-59, out.

Comassetto, Vilmar. (2000), Conselhos municipais e democracia participativa sob o contexto do desenvolvimento sustentável na percepção dos prefeitos municipais. Dissertação de Mestrado. Programa de Pós-Graduação em Engenharia de Produção. Florianópolis: Universidade Federal de Santa Catarina.

CORREIO Do Povo. (2001), “Cresce a busca de emancipação”, p. 2

Costa, Alcides. (1996), Reforma tributária: uma visão histórica. Mimeo (http:// www.federativo.bndes.gov.br/f_estudo.htm).

CosTA, Sergio. (1997), "Movimentos sociais, democratização e a construção de esferas públicas locais". Revista Brasileira de Ciências Sociais, São Paulo, vol. 12(35), p. 121-135, out.

CRUZ, Maria. (2001), Consórcios intermunicipais: uma alternativa de integração regional ascendente. São Paulo: PÓLIS/EAESP/FGV.

CURCHIN, Leonard. (1990), The Local Magistrates of Roman Spain. Toronto: University of Toronto Press.

Decentralization Thematic Team (DTT). (2001), Accountability, Transparency and Corruption in Decentralized Governance. Acessado 02.05 (http://www.ciesin.org/ decentralization/english/issues/accountability.html).

DLG - Research Program on Democracy and Local Governance. Acessado 20.5.2001 (http://www.ssc.upenn.edu/dlg).

ElLIot, Jeffrey; Ali, Sheikh. (1995), "The State and Local Government Political Dictionary". Borgo Reference Guides no 7, San Bernardino: The Borgo Press.

Estado do Rio Grande do Sul. Secretaria de Planejamento. (1963), Constituições SulRiograndenses 1843-1947. Porto Alegre: Imprensa Oficial.

FARAH, Marta. (2001), "Parcerias, novos arranjos institucionais e políticas públicas no nível local de governo". Revista de Administração Pública, Rio de Janeiro, vol. 35 (1), p.119-144, jan/fev.

FERREIRA, Manoel. (1980), As repúblicas municipais no Brasil (1532-1820). São Paulo: Secretaria Municipal de Cultura.

FIGUEIREDO, Rubens. (1997), "Marketing político - mitos e verdades", in Jung, Wilfried (org.), Comportamento eleitoral e marketing político: as novas prefeituras brasileiras. Série Papers. São Paulo: Fundação Konrad Adenauer.

Fleischer, David. (1996), "Poder local e o sistema eleitoral brasileiro", in Jung, Winfried (org.), Poder local face às eleições de 1996. Série Debates no 10. São Paulo: Fundação Konrad Adenauer. 
Freitas, Almir. (2001), “Também temos os 'pais da pátria'”. Revista República, São Paulo, ano 5(58), p. 92-94, ago.

FRIEDMANN, John. (1960), Introdução ao planejamento regional. Com ênfase na Amazônia. (US Mission to Brazil). Tradução Mário Faustino. Rio de Janeiro: FGV.

FundaÇão de EConomia e Estatística - FEE. (1999), Resumo estatístico municipal. CD-ROM Versão 11/97. Porto Alegre: FEE.

Fundação GETÚLIO VARGAS — FGV/EAESP. (2000), Manual de orientação para crescimento da receita própria municipal. São Paulo: FGV/BNDES.

GALSTERER, Hartmut. (1971), Untersuchungen zum römischen Städtewesen auf der iberischen Halbinsel. Berlin: Walter de Guyter.

Garcia, Ronaldo. (1995), "Descentralização: um processo a ser acompanhado e avaliado (ou do finja que eu finjo ao faça que nós vemos)". Texto para Discussão $n^{\circ}$ 364, Brasília: IPEA.

Gazeta Mercantil. (2001), "Integração regional passa pelo FONPLATA", p.12.

Guimarães, Arthur. (1904), Questões econômicas nacionais. Lisboa: Typhographia da A Editora.

Gomes, Gustavo; Macdowell, Márcia. (2000), "Descentralização política, federalismo fiscal e criação de municípios: o que é mau para o econômico nem sempre é bom para o social". Texto para discussão n 706, Brasília: IPEA.

Gondim, Linda. (2000), “Os ‘Governos das Mudanças' (1987-1994)”, in SouzA, Simone (org.), Uma nova história do Ceará. Fortaleza: Edições Demócrito Rocha.

Hildebrand, Mary; Grindle, Merilee. (1997), "Building Sustainable Capacity in the Public Sector. What can be done?", in GrindLE, M. (ed.), Getting Good Government: Capacity Building in the Public Sectors of Developing Countries. Cambridge: Harvard University Press.

Instituto Brasileiro de Geografia e Estatística (IBGE). (2001), Perfil dos municípios brasileiros: pesquisa de informações básicas municipais 1999. Rio de Janeiro: IBGE.

JACOBI, Pedro. (2000), Políticas sociais e ampliação da cidadania. Rio de Janeiro: FGV.

JAMESON, Samuel. (1965), “Administração municipal”. Textos Selecionados de Administração Pública, vol. 10. Rio de Janeiro: Centro de Publicações Técnicas da Missão NorteAmericana de Cooperação Econômica e Técnica/USAID e FGV.

JoRdAN, Terry. (2001), The U.S. Constitution and Fascinating Facts About It. Naperville: OakHill Company.

KLERING, Luis. (1998), "Experiências recentes em municípios brasileiros. Os novos municípios e as conquistas da autonomia", in FAchin, R., CHANLAT, A. (orgs), Governo municipal na América Latina. Porto Alegre: Sulina/EDUFRGS.

KRAFT, Lothar. (1995), Formação política e educação para a cidadania. São Paulo: Fundação Konrad Adenauer.

Lagemann, Eugenio; Bordin, Luis. (1993), Descentralização fiscal no Brasil: a percepção do Estado do Rio Grande do Sul. Projeto CEPAL/GTZ. Porto Alegre: Secretaria da Fazenda.

Lima, Maria; Cheibub, Zairo. (1996), "Instituições e valores. As dimensões da democracia na visão da elite brasileira”. Revista Brasileira de Ciências Sociais, São Paulo, no 31, p. 83-110, junho.

Llambi, Luis; Lindemann, Tomás. (2001), State Reforms and the Decentralization of the Agricultural and Rural Public Sector: Lessons from the Latin American Experience. Roma: FAO. (http://www.fao.org/sd/2001/IN0502a_en.htm).

Machado, Marina. (1966), O ensino da administração pública no Brasil. Rio de Janeiro: FGV. MACKIE, Nicola. (1983), Local Administration in Roman Spain AD 14-212. Oxford: BAR. Magalhães, José (org.). (2000), "Pacto federativo". Caderno de Pesquisa $n^{\circ}$ 1, Belo Horizonte: Mandamentos. 
Manin, Bernard. (1995), “As metamorfoses do governo representativo”. Revista Brasileira de Ciências Sociais, São Paulo, vol. 10(29), p. 5-34, outubro.

Medici, André; Maciel, Marco. (1994), "A dinâmica do gasto social nas três esferas de governo: 1980-92”, in Affonso, R., Silva, P. (orgs.), Descentralização e políticas sociais. São Paulo: FUNDAP.

MeIrelles, Hely. (1977), Direito municipal brasileiro. 3a ed. São Paulo: Ed. Revista dos Tribunais.

Melo, Marcus. (1993), "Municipalismo, Nation Building e a modernização do Estado no Brasil”. Revista Brasileira de Ciências Sociais, São Paulo, no 23, ano 8, p. 85-100, outubro.

Mendonza, Enrique; LiRa, José. (1998), “O município como o eixo principal da descentralização no México”, in FACHIN, R., CHANLAT, A. (orgs), Governo municipal na América Latina. Porto Alegre: Sulina/EDUFRGS.

Montoro, Franco. (1990), Participação: desenvolvimento com democracia. São Paulo: Nossa Editora.

Oliverra, Yves. (1958), Curso de direito municipal. Rio Janeiro: Livraria Freitas Bastos.

Operations Evaluation Department (OED). (1998), "Impact Evaluation Report. Building Institutions and Financing Local Development: Lessons from Brazil and the Philippines". Report no 18727. Washington: World Bank, december.

. (OED). (2001), "Brazil. Financing Municipal Investment. Issues and Options". Report no 20313-BR. Washington: World Bank.

PARAnACIDAdE. Serviços Social Autônomo. Acessado 13.8.2001. (http://www.paranacidade. org.br).

Pnud/IPEA/Fup/IbGe. (1998), Desenvolvimento humano e condições de vida: indicadores brasileiros. Brasília: PNUD.

ReID, Norman. (2000), Community Participation. How People Power brings Sustainable Benefits to Communities. USDA Rural Development, june. (http://www.ezec.gov/Pubs/ commparticrept.pdf).

RESENDE, Luis. (2000), “Comunidade solidária: uma alternativa aos fundos sociais". Texto para Discussão $n^{-}$725, Brasília: IPEA.

Resende-Santos, João. (2001), "Democracy, Equity, and Governance in Brazil". Latin American Research Review, Pittsburg, vol. 36(1), p.207-237.

SAngra, Emmanuel. (2000), Evaluation and Civil Society. The Example of The Canton of Geneva. Paper apresentado no 4ํ Conference of the European Evaluation Society, out. (http://www.europeanevaluation.org).

SATO, Ademar. (1993), "Descentralização: um tema complexo". Texto para Discussão $n^{\circ}$ 314, Brasília: IPEA.

SAule Junior, Nelson. (1997), Novas perspectivas do direito urbanístico brasileiro. Ordenamento constitucional da política urbana, aplicação e eficácia do plano diretor. Porto Alegre: Sergio Antonio Fabris Editor.

Fundação Sistema Estadual de AnÁlise de Dados (SEADE). (2001), Índice paulista de responsabilidade social. São Paulo: Fórum Século XXI.

Silva, Carlos. (1952), Direito público municipal e administração dos municípios. Belo Horizonte: Edições Mantiqueira.

SмIтн, William. A Dictionary of Greek and Roman Antiquities. London: John Murray, 1875 in: http://www.ukans.edu/history/index/europe/ancient_rome/E/Roman/Texts.

Songco, Danito. (2001), Accountability to the Poor: Experiences in Civic Engagement in Public Expenditure Management. Washington: World Bank. (http://www.worldbank.org/ participation). 
SouzA, Celina. (1998), "Dez anos de descentralização: a experiência dos municípios brasileiros", in FACHIN, R., ChANLAT, A. (orgs.), Governo municipal na América Latina. Porto Alegre: Sulina/EDUFRGS.

. (2001), "Federalismo e gasto social no Brasil: tensões e tendências". Revista Lua Nova, São Paulo, 52, p. 5-28.

SouzA, Iara. (1999), Pátria coroada: o Brasil como corpo político autônomo 1780/1831. São Paulo: Ed. UNESP

Superintendência do Desenvolvimento Urbano e Administração Municipal (SURBAM). (1988), Administrando o Município. Porto Alegre: Secretaria do Interior, Desenvolvimento Regional e Urbano e Obras Públicas.

Tendler, Judith. (1998), Bom Governo nos Trópicos - Uma visão crítica. Tradução de Maria Cupertino. Rio de Janeiro/Brasília: Revan/ENAP.

Turner, Mark (ed.). (1999), Central-Local Relations in Asia Pacific: Convergence or Divergence?. London: Macmillan.

VeIgA, José. (2000), A face rural do desenvolvimento. Natureza, território e agricultura. Porto Alegre: Ed. Universidade/UFRGS.

VÉROn, René. (2001), “The 'New’ Kerala Model: Lessons for Sustainable Development”. World Development, London, vol. 29(4), p.601-617.

VIVERET, Patrick. (2001), "Por uma soberania ascendente". Cadernos Le Monde diplomatique. Edição Especial Fórum Social Mundial, p. 8, janeiro.

World BANK. (2001), Decentralization NET. Acessado 5.07.2001 (http://ww1.worldbank. org/ publicsector/decentralization/more.htm).

Zero Hora. (2001), "Imprensa”. 25. 07, p. 3. . (2001), "Um em cada 10 gaúchos está na indigência”. 30.08. p. 4. 
Revista do Serviço Público

Markus Brose

Secretaria de

Planejamento

do Rio Grande

do Sul e

mestrando

em Public

Policy and

Management pela

Universidade de Londres.

Contato: mbrose@ uol.com.br

\section{Abstract}

\section{Descentralização e good government: como aperfeiçoar o desempenho dos governos locais?}

\section{Markus Brose}

O país vem passando por um acelerado processo de descentralização desde a Constituição de 1988. Os Governos Locais vem recebendo uma carga de atribuições crescente, sem que haja um planejamento ou um debate na sociedade sobre os limites deste processo. Além disso, não ocorre a descentralização fiscal necessária como contrapartida. Seguindo uma longa tradição histórica, os Governos Federal e Estaduais não confiam nos Governos Locais e vem criando uma série de mecanismos de pressão e controle sobre os Governos Locais. Por meio de uma pesquisa realizada junto a municípios de caráter rural no Rio Grande do Sul, foi efetuado um diagnóstico acerca da percepção de lideranças locais sobre este processo. Ao final, é proposta uma inversão da lógica atual: fortalecer a capacidade de autogestão dos Governos Locais.

\section{Descentralización y good government: como perfeccionar el desempeño de los gobiernos locales?}

Markus Brose

El país viene pasando por un acelerado proceso de descentralización desde la Constitución de 1988. Los Gobiernos Locales están recibiendo una carga creciente de atribuciones, sin haber un planeamiento o un debate en la sociedad acerca de los límites de ese proceso. Además, no ocurre la descentralización fiscal necesaria como contrapartida. Conforme una longa tradición histórica, los Gobiernos Federal y Estaduales no confián en los Gobiernos Locales y vienen creando una serie de mecanismos de presión y control sobre los Gobiernos Locales. Por medio de una pesquisa realizada junto a municipios de carácter rural en el Rio Grande do Sul, fue efectuado un diagnóstico sobre la percepción de líderes locales sobre ese proceso. Al final, es propuesta una inversión de la lógica actual: fortalecer la capacidade de autogestión de los Goviernos Locales.

\section{Decentralization and good government: how to improve the capacity of local government? \\ Markus Brose}

Since the new Constituition of 1988 the country is undergoing a rapid process of decentralization. The Local Government is receiving new duties, without a previous process of planning or a public debate about the limits of this process. There is also no process of decentralization of resources to the Local Governmnet. Within a historical tradition the Federal Government anb the Regional Governments dont trust the Local Government, and are creating new forms of control and pressure over it. This article describes a reasearch undertaken with stakeholders within small countys in the state of Rio Grande do Sul about their perception of this process. At the end of the article there are presented proposals in order to reverse the process: how to strengthen the capacity of Local Governments, instead of only controlling them. 

Nacional de Administração Pública, voltada para a divulgação e debate de temas relacionados ao Estado, à administração pública e à gestão governamental. Procurando o aprimoramento permanente da revista, tanto no seu conteúdo quanto na apresentação gráfica, pedimos aos nossos colaboradores a observação das normas abaixo descritas.

\section{Normas para os colaboradores}

1. Os artigos, sempre inéditos no Brasil, devem conter em torno de 25 laudas de 20 linhas de 70 toques.

2. Os originais devem ser encaminhados ao editor, em arquivo digital, em programa de uso universal e enviados para editora@enap.gov.br. Usar apenas as formatações-padrão.

3. Cada artigo deve vir acompanhado de um resumo analítico em português, espanhol e inglês, de cerca de 150 palavras, que permita uma visão global e antecipada do assunto tratado.

4. Na primeira página do artigo, deve constar informação sobre formação e vinculação institucional do autor (em até duas linhas).

5. Notas, referências e bibliografia devem vir ao final do artigo, e não ao pé da página. Notas e referências, sendo o caso, devem vir devidamente numeradas.

6. Além de artigos, a revista receberá comunicações, notas informativas, notícias e relatórios conclusivos de pesquisas em desenvolvimento, com até 15 laudas. Resenhas de livros, em torno de 4 laudas, devem conter uma apresentação sucinta da obra e eventuais comentários que situem o leitor na discussão.

7. Os trabalhos que se adequarem à linha temática da revista serão apreciados pelo conselho editorial, que decidirá sobre a publicação com base em pareceres de consultores ad hoc.

8. Os originais enviados à Revista do Serviço Público não serão devolvidos. A revista compromete-se a informar os autores sobre a publicação ou não de seus trabalhos.

\section{Convite a resenhadores}

A Revista do Serviço Público convida todos os interessados em remeter resenhas de trabalhos publicados no Brasil e no exterior sobre Estado, administração pública e gestão governamental.

As resenhas devem ser originais e não exceder a cinco laudas datilografadas em espaço duplo com 20 linhas de 70 toques, e devem apresentar de modo sucinto a obra, com comentários que situem o leitor na discussão apresentada.

As resenhas devem ser enviadas em português, sem notas de rodapé, contendo o título completo e subtítulo do livro, nome completo do autor, local de publicação, editora e ano de publicação, bem como uma breve informação sobre a formação e vinculação institucional do resenhador (em até duas linhas), acompanhadas do respectivo disquete.

\section{Nota aos editores}

Pedimos encaminhar à Revista do Serviço Público exemplares de livros publicados, a fim de serem resenhados. Os resenhadores interessados receberão cópias dos livros enviados. 
Cadernos ENAP

Números publicados

20 Metodologia para medir a satisfação do usuário no Canadá: desfazendo mitos e redesenhando roteiros Geoff Dinsdale \& D. Brian Marson Faye Schmidt \& Teresa Strickland — 2000

19 Experiências de Avaliação de Desempenho na Administração Pública Federal Pesquisa ENAP — 2000

18 Reforma administrativa e relações trabalhistas no setor público Zairo B. Cheibub \& Richard M. Locke - 1999

17 Gerenciando a alta administração pública: uma pesquisa em países da OCDE

Organização de Cooperação e Desenvolvimento Econômico — 1999

16 Flexibilidade na gestão de pessoal da administração pública OCDE - Organização de Cooperação e Desenvolvimento Econômico - 1998

15 O processo decisório da reforma tributária e da previdência social Marcus André de Melo \& Sérgio Azevedo - 1998

14 Gerência de recursos humanos no setor público: lições da reforma em países desenvolvidos Barbara Nunberg — 1997

13 Reforma do Estado no setor de saúde: os casos da Catalunha, Canadá, Reino Unido e Estados Unidos

Samuel Husenman \& Emili Sullà e outros — 1997

12 Normas de conduta para a vida pública Lord Nolan — 1997

11 A seguridade social no Brasil e os obstáculos institucionais à sua implementação Pedro César Lima de Farias — 1997

10 O Impacto do modelo gerencial na administração pública Fernando Luiz Abrucio — 1997

9 Progressos recentes no financiamento da previdência social na América Latina Manfred Nitsch \& Helmut Schwarzer - 1996

8 Reforma da Administração Pública e cultura política no Brasil Luciano Martins — 1997

7 Reforma do Estado Evandro Ferreira Vasconcelos e outros - 1994

6 Planejamento e orçamento Fábio Chaves Holanda e outros — 1994 
5 Recursos humanos no setor público

Marcelo Viana Estevão de Moraes e outros — 1994

4 A questão social no Brasil

Marcos Torres de Oliveira e outros - 1994

3 Gestão municipal e revisão constitucional

Luíza Erundina de Souza e outros — 1993

2 Cultura e memória na Administração Pública brasileira Iveraldo Lucena e outros — 1993

1 Gestão de recursos humanos, relações de trabalho e direitos sociais dos servidores públicos

Técnicos da ENAP e colaboradores - 1993 
Texto para discussão

Números publicados

47 Três exemplos de mudanças na gestão de suprimentos na Administração Pública Federal: UFSM, GHC e $4^{\circ}$ RCC Pesquisa ENAP — maio 2002

46 A hegemonia do SUS e a relação público/privado na assistência hospitalar

Susete Barbosa França — abril 2002

45 A conceituação de governabilidade e governança, da sua relação entre si e com o conjunto da reforma do Estado e do seu aparelho Vinícius de Carvalho Araújo — março 2002

44 Reforma gerencial dos processos de planejamento e orçamento Fabiano Garcia Core - outubro 2001

43 Os Especialistas em Políticas Públicas e Gestão governamental: avaliação de sua contribuição para políticas públicas e trajetória profissional

Zairo B. Chaibub e Wânia Amélia Belchior Mesquita — agosto 2001

42 Experiências internacionais voltadas para a satisfação dos usuárioscidadãos com os serviços públicos Pesquisa ENAP — maio 2001

41 Gestão de custos no setor público Pesquisa ENAP — março 2001

40 Entre o público e o privado: O modelo de gestão de resíduos sólidos adotado pela SLU de Belo Horizonte José Wanderley Novato Silva e Allan Claudius Queiroz Barbosa fevereiro 2001

39 A percepção das chefias sobre a capacitação nos cursos da ENAP Pesquisa ENAP — dezembro 2000

38 Perfil dos dirigentes de recursos humanos na Administração Pública Federal

Pesquisa ENAP — novembro 2000

37 Planejamento estratégico municipal no Brasil: uma nova abordagem Peter Pfeiffer — outubro 2000

36 Relatório de avaliação do curso Elaboração de indicadores de desempenho institucional

Pesquisa ENAP — outubro 2000

35 Modelo para informatização das administrações públicas municipais Maria José Ferreira Foregatto Margarido — agosto 2000

34 Perfil dos gestores de recursos humanos da Administração Pública Federal

Pesquisa ENAP — agosto 2000 
33 A imanência do planejamento e da gestão: a experiência de Curitiba Luiz Carlos de Oliveira Cecílio, Carlos Homero Giacomini \& Miguel Ostoja Roguski — agosto 1999

32 Sociedade civil: sua democratização para a reforma do Estado Luiz Carlos Bresser Pereira — novembro 1998

31 Custos no serviço público Marcos Alonso Nunes — outubro 1998

30 Demissão por insuficiência de desempenho na reforma gerencial: avanços e desafios Marianne Nassuno - setembro 1998

29 Reforma da previdência: negociações entre os poderes Legislativo e Executivo Marcelo James Vasconcelos Coutinho - agosto 1998

28 Diagnóstico da situação da mulher na Administração Pública Federal Franco César Bernardes, Marcelo Gameiro de Moura \& Marco Antônio de Castilhos Acco — julho 1998

27 Capacitação de recursos humanos no serviço público: problemas e impasses Francisco Gaetani — junho 1998

26 Análise de macroprocessos na Secretaria de Recursos Humanos do MARE: uma abordagem sistêmica Marcelo de Matos Ramos — maio 1998

25 Desafios e oportunidades no setor de compras governamentais na América Latina e Caribe: o caso brasileiro Carlos César Pimenta — abril 1998

24 Reconstruindo um novo Estado na América Latina Luiz Carlos Bresser Pereira — março 1998

23 Reforma administrativa e direito adquirido Paulo Modesto - fevereiro 1998

22 Utilizando a internet na administração pública Cláudio Seiji Sato — dezembro 1997

21 Burocracia, capacidade de Estado e mudança estrutural Tereza Cristina Cotta — novembro 1997

20 A reforma administrativa francesa: da crise da função pública a uma nova racionalidade da ação coletiva, uma difícil transição Valdei Araújo — outubro 1997

19 Formação e capacitação na construção de um novo Estado Evelyn Levy — setembro 1997

18 Agências Executivas: estratégias de reforma administrativa Marcos Alonso Nunes — agosto 1997 
17 Controle interno e paradigma gerencial

Sheila Maria Reis Ribeiro — julho 1997

16 Novos padrões gerenciais no setor público: medidas do governo americano orientadas para o desempenho e resultados

Bianor Scelza Cavalcanti \&Roberto Bevilacqua Otero — junho 1997

15 Cidadania e Res publica: a emergência dos direitos republicanos Luiz Carlos Bresser Pereira — maio 1997

14 Gestão e avaliação de políticas e programas sociais: subsídios para discussão Francisco Gaetani — abril 1997

13 As escolas e institutos de administração pública na América Latina diante da crise do Estado Enrique Saravia — março 1997

12 A modernização do Estado: as lições de uma experiência Serge Vallemont — dezembro 1996

11 Governabilidade, governança e capacidade governativa Maria Helena de Castro Santos — dezembro 1996

10 Qual Estado? Mário Cesar Flores — novembro 1996

9 Administração pública gerencial: estratégia e estrutura para um novo Estado Luiz Carlos Bresser Pereira — outubro 1996

8 Desempenho e controle na reforma administrativa Simon Schwartzman — setembro 1996

7 Brasil século XXI - A construção de um Estado eficaz Virginio Augusto Ferreira Coutinho \& Maria Teresa Oliva Silveira Campos — agosto 1996

6 A tecnologia da informação na reforma do Estado Ricardo Adolfo de Campos Saur — julho 1996

5 Reforma administrativa e direito adquirido ao regime da função pública Paulo Modesto — outubro 1995

4 Estado, aparelho do Estado e sociedade civil Luiz Carlos Bresser Pereira - outubro 1995

3 Reflexões sobre a proposta da reforma do Estado brasileiro Gleisi Heisler Neves — outubro 1995

2 A questão da estabilidade do serviço público no Brasil: perspectivas de flexibilização Érica Mássimo Machado \& Lícia Maria Umbelino — julho 1995

1 A reforma do aparelho do Estado e a Constituição brasileira Luiz Carlos Bresser Pereira — maio 1995 


\section{Solicitação de publicações}

Nome/Instituição:

\section{CPF/CNPJ:}

Endereço:

\begin{tabular}{lcc}
\hline Cidade: & UF: & CEP: \\
\hline Telefone: & Fax: & \\
\hline E-mail: & &
\end{tabular}

\section{Cartão de assinatura da RSP}

Periodicidade: trimestral

Assinatura anual: $\mathrm{R} \$ 40,00$

Ano 53-2002

- Número avulso: R\$ 12,00 Edição $n^{\circ}$

- Exemplar avulso anterior a 1997: $\mathrm{R} \$ 8,00$

\section{Cadernos ENAP}

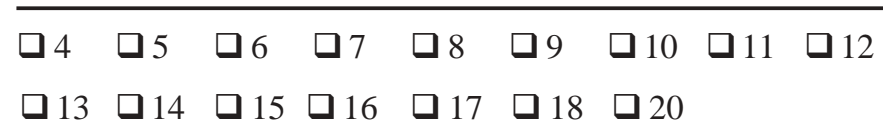

Preço unitário: $R \$ 10,00$

\section{Texto para discussão}

\begin{tabular}{llllllllll}
\hline$\square 1$ & $\square 2$ & $\square 3$ & $\square 4$ & $\square 5$ & $\square 6$ & $\square 7$ & $\square 8$ & $\square 9$ & $\square 10$ \\
$\square 11$ & $\square 12$ & $\square 13$ & $\square 14$ & $\square 15$ & $\square 16$ & $\square 17$ & $\square 18$ & $\square 19$ & $\square 20$ \\
$\square 21$ & $\square 22$ & $\square 23$ & $\square 24$ & $\square 25$ & $\square 26$ & $\square 27$ & $\square 28$ & $\square 29$ & $\square 30$ \\
$\square 31$ & $\square 32$ & $\square 33$ & $\square 34$ & $\square 35$ & $\square 36$ & $\square 37$ & $\square 38$ & $\square 39$ & $\square 40$ \\
$\square 41$ & $\square 42$ & $\square 43$ & $\square 44$ & $\square 45$ & $\square 46$ & $\square 47$ & & &
\end{tabular}

Preço unitário: $R \$ 5,00$

Forma de pagamento ver orientação no verso

Cheque nominal $\square$ Ordem de pagamento $\square$ Nota de empenho 


\section{Forma de pagamento}

- Cheque nominal à ENAP Fundação Escola Nacional de Administração Pública.

- Ordem de pagamento (anexar cópia do comprovante de depósito) em nome da ENAP Escola Nacional de Administração Pública, através do Banco do Brasil S/A, Agência Ministério da Fazenda 3602-1, Conta Corrente: 170500-8 Depósito identificado (código - dv) finalidade: 11470211401002-2.

- Nota de empenho em nome da ENAP Escola Nacional de Administração Pública (anexar original). (UG:114702, Gestão: 11401).

ENAP Escola Nacional de Administração Pública

Diretoria de Informação e Conhecimento em Gestão

SAIS - Área 2-A

70610-900 - Brasília, DF

Tel: (61) 445 7096/ 4457102 -Fax: (61) 4457178

CNPJ: 00627 612/0001-09

Site: www.enap.gov.br

E-mail: publicacoes@enap.gov.br 